\title{
Kurdish Nation and the use of mother tounge as a cosmical right
}

\author{
Sherko Hama-Amin Qadr ${ }^{1}$, Brwa Rasool Ahmad
}

Received: August 10, 2016

Reviewed: August 17, 2016

Accepted: September 05, 2016

\begin{abstract}
This research is an attempt to revelate the rule of language in developing and sustenate nation's culture, especially the nations who have a national ancient culture like Kurd. The above little considers the Kurdish Language for sustenate an unstate Kurdish nation in order to remains as a national different custom among the neighborhood nations, and these will be ensured in the all scopes with the using of mother tongue. The right of using mother tongue was proved directly or indirectly in all religions, world agreements, human rights and democratic state constitutions. In other word there is no justification to prohibit the right of using mother tongue in the different scopes of society. Language is a basic factor for remaining and the perishing the nations, it is also a main dimension of constructing the ken of the nation. Looking at the history will show us that there were many languages disappeared due to political reasons or neglecting. Kurd as an ancient nation has its own language which consists of some different dialects, but the dominant tried to perish it, by some means or other a kind of language assimilation was tried, but the reaction was there to defend and protect the language. Now Kurdish language is spoken only in a part of Kurdistan "South Kurdistan", beside Arabic Language Kurdish was also confessed in Iraqi constitution. This research which is fallen in with apply linguistics, prescriptive explanations will be performed. The research consists of an introduction and two chapters. $\mathrm{n}$ the first chapter language and Kurdish language, the connection between language and nations and the characteristics of a national language will be talked about. The second chapter is dedicated to talk about mother language and using mother language as a sustained right, and proving this cosmical in the international agreements and democratic state constitutions. Meanwhile exposition of the importance of using Kurdish national language in all stages especially in the education in both governmental and nongovernmental sectors. At the end the most important gained results and the list of bibliography will be showed.
\end{abstract}

\section{Recommended citation:}

Qadr, S. H. \& Ahmad, B. R. (2016). Kurdish Nation and the use of mother tounge as a cosmical right. International Journal of Kurdish Studies 2 (3), 219 - 237.

\footnotetext{
${ }^{1}$ Associate professor and member of parliament in Kurdistan Region of Iraq. Email: sherkohamaamin@gmail.com

${ }^{2}$ Assistant Lecturer, Department of Kurdish language, Faculty of education, Raparin University

Ranya, Sulaimani, Kurdistan Region - F.R. Iraq. email; brwalinguistic@ gmail.com
} 


\section{نهتهوهى كورد و باككار هينانى زمانى دايك وهك مافيّكى كلهردونى شيْرِكو حهمهائهمين قادر بروا إرسول ئهحملند}

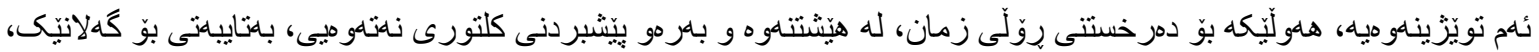

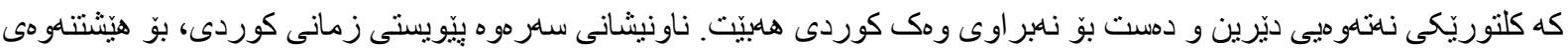

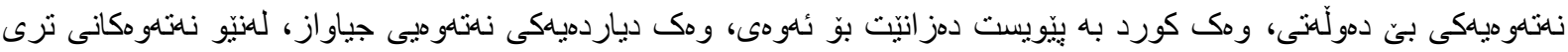

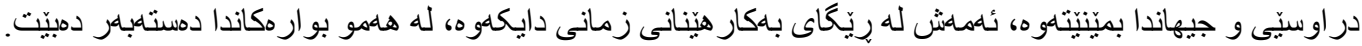

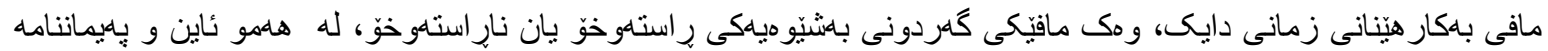

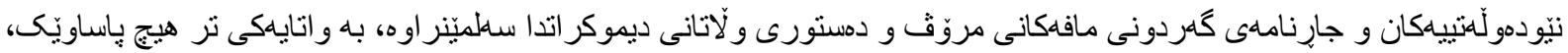

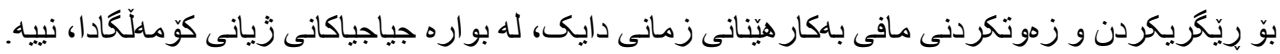

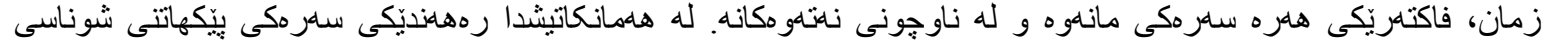

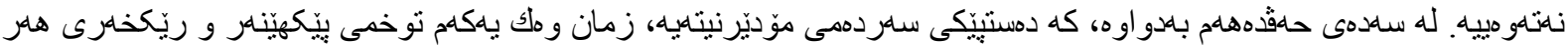

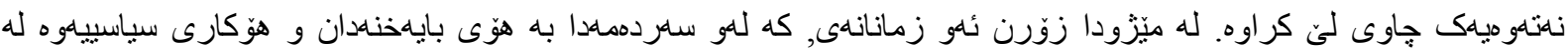

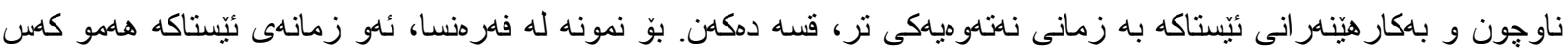

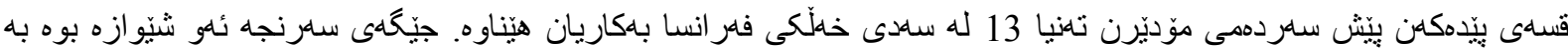

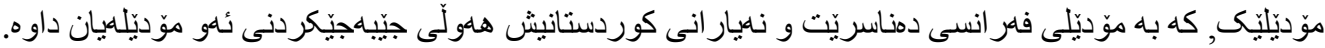

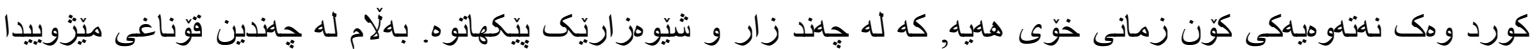

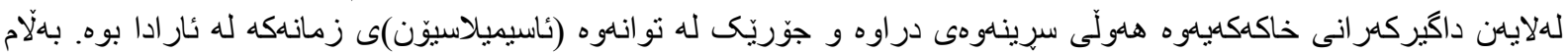

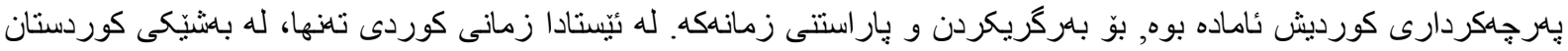

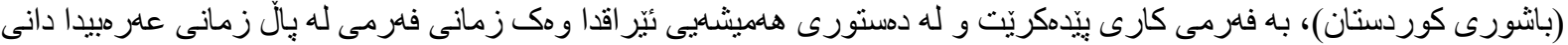

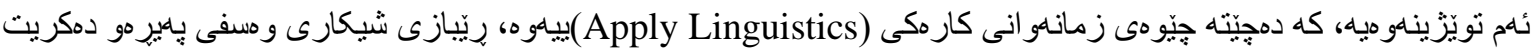

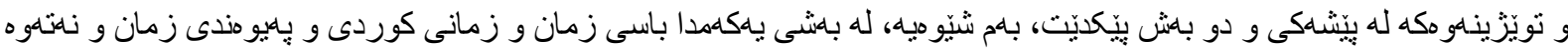

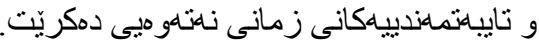

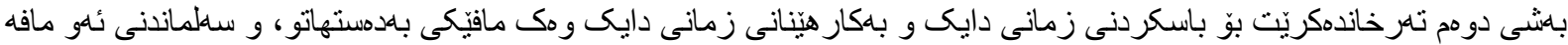

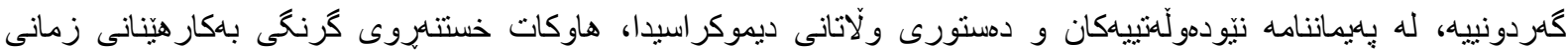

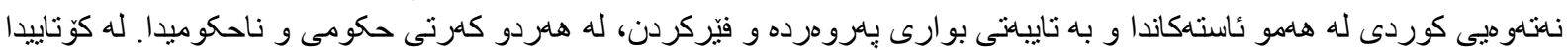

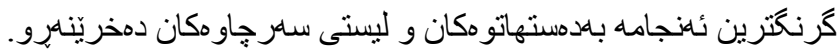




\section{بالششى ياكلم}

زمان

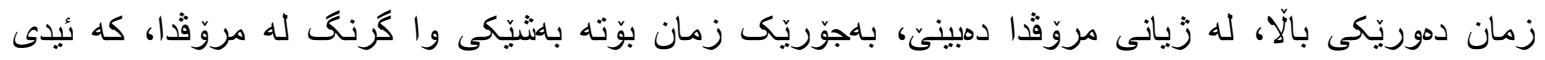

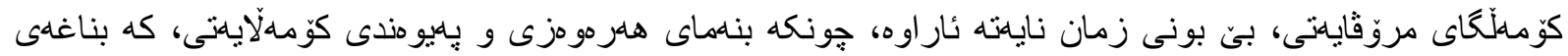

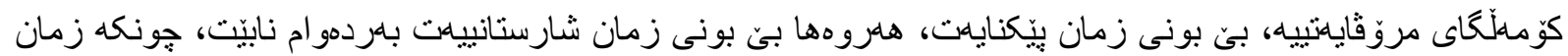

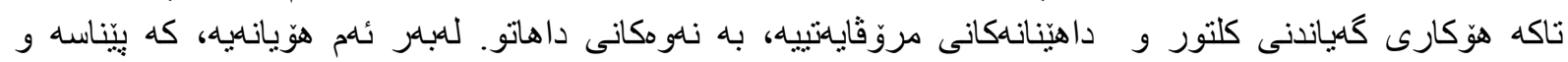

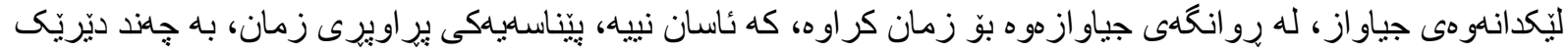

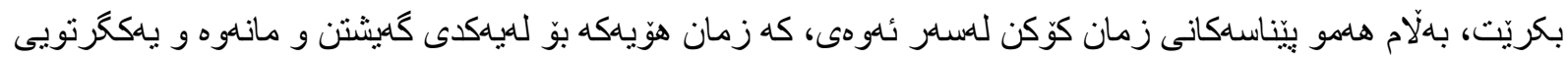

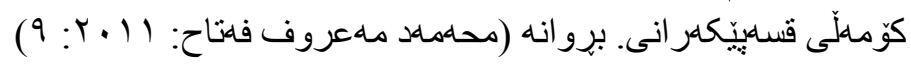

زمانى كوردى و تايبهتمهندى زمانى كوردى

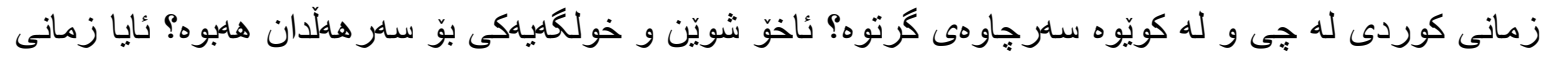

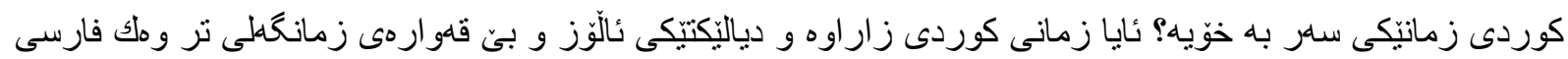

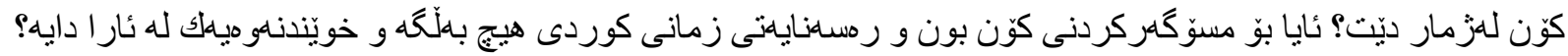

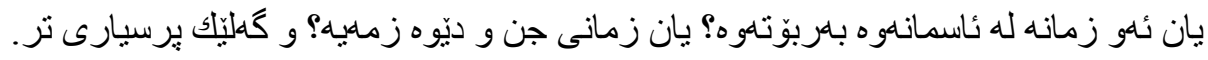

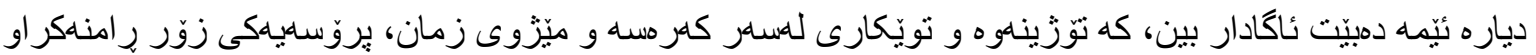

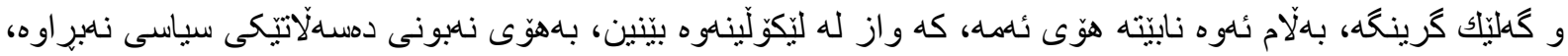

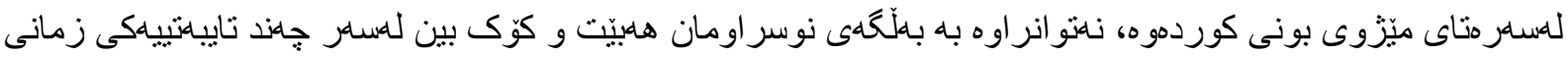

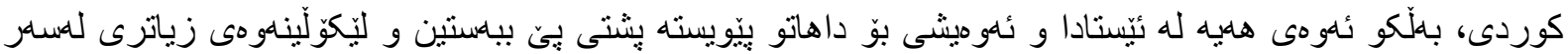

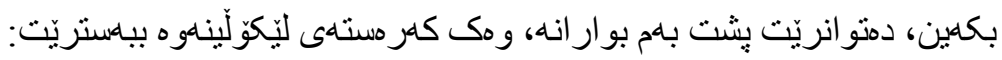

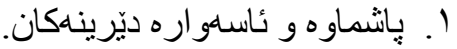

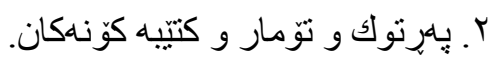

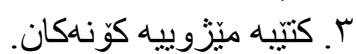

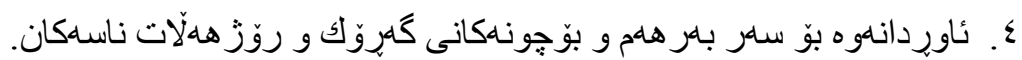

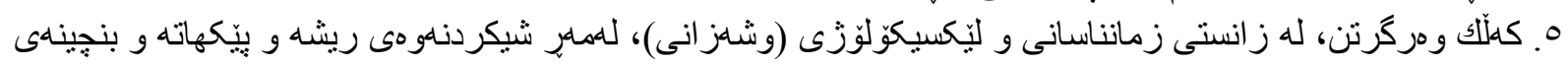

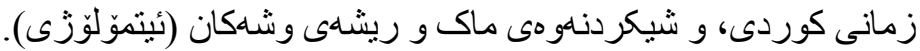

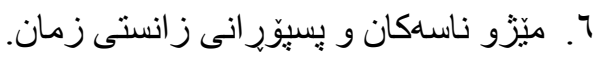

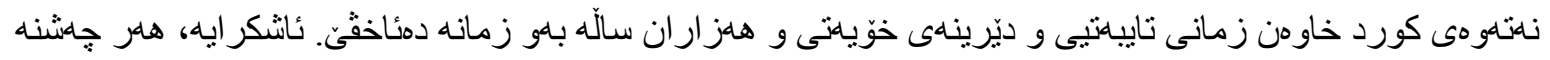

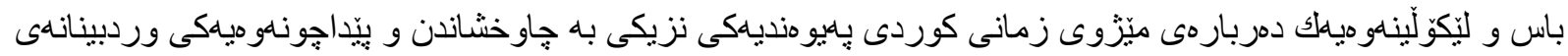

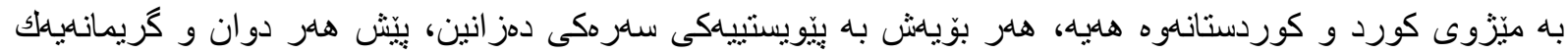

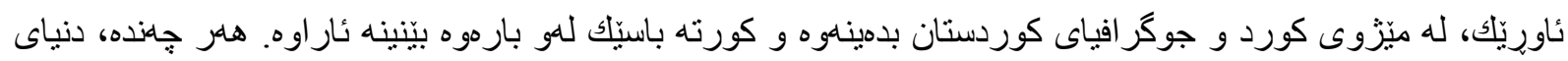

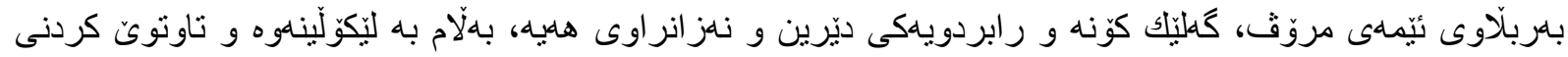

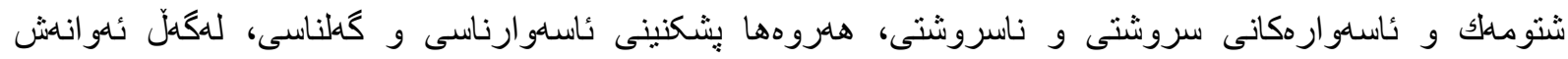

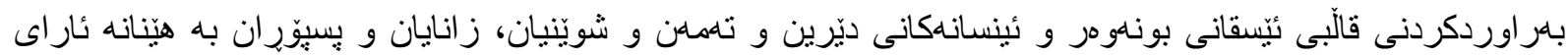

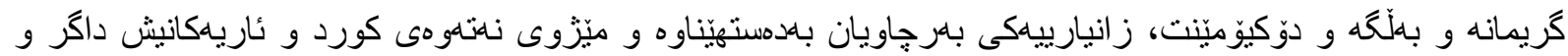

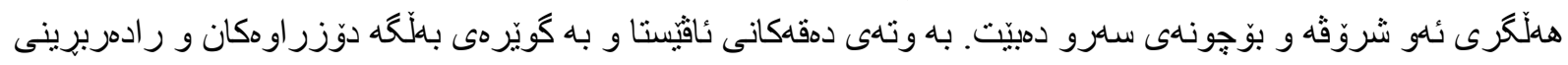

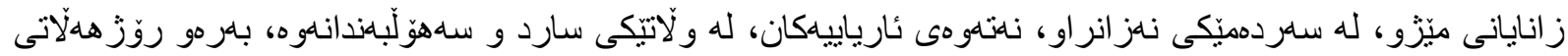




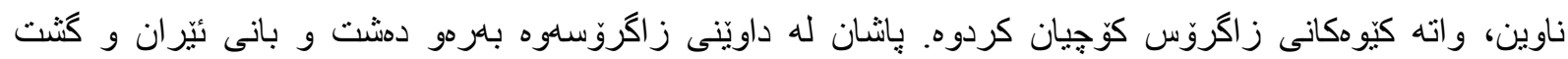

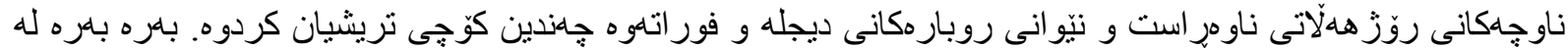

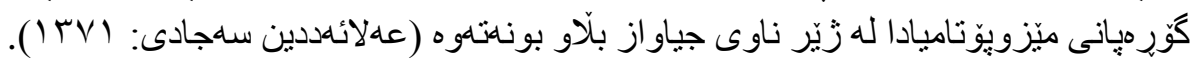

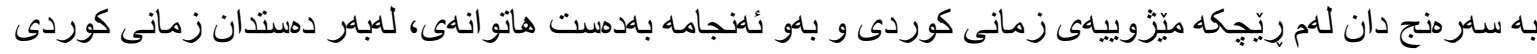

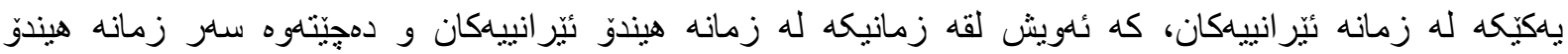

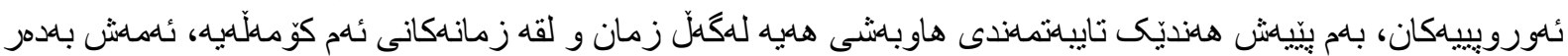

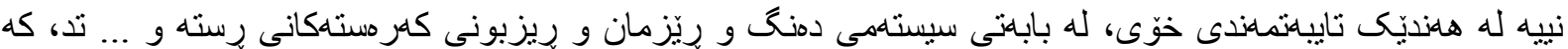

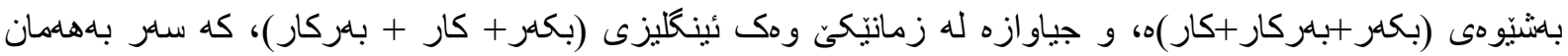

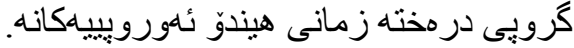

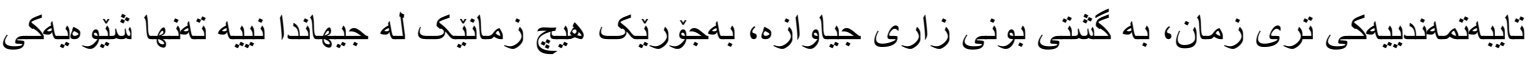

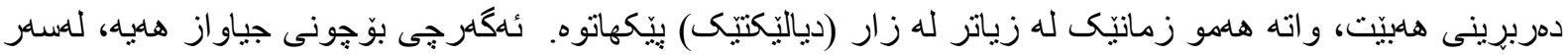

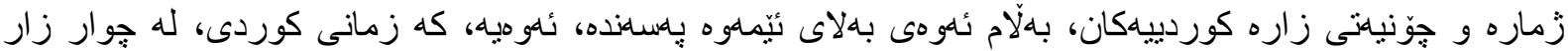

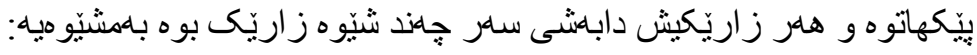

$$
\begin{aligned}
& \text { • زارى كرمانجى سارو } \\
& \text { • زارى كرمانجى ناو مر است دئ }
\end{aligned}
$$

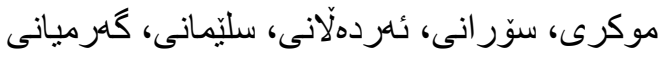

$$
\begin{aligned}
& \text { • زارى كوّران }
\end{aligned}
$$

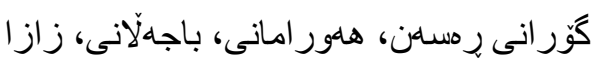

$$
\begin{aligned}
& \text { • ارى كرمانجى خوارو }
\end{aligned}
$$

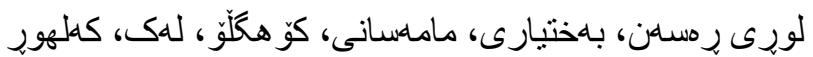

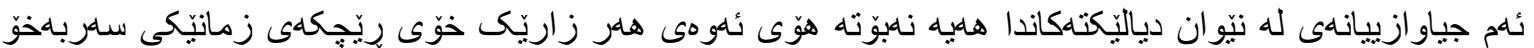

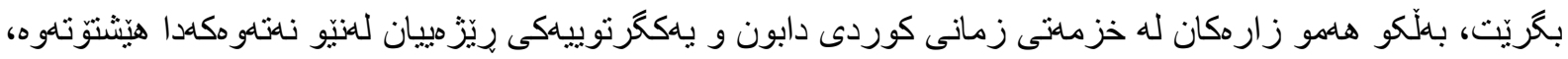

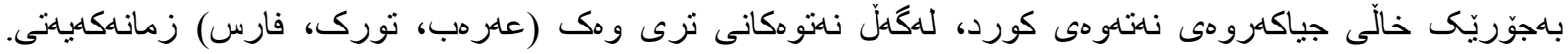

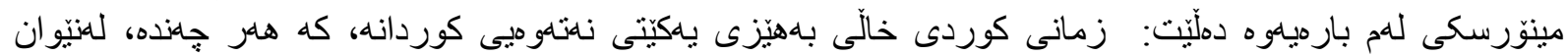

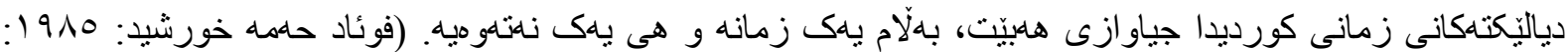

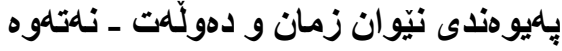

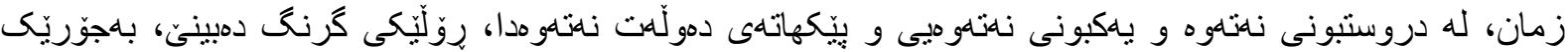

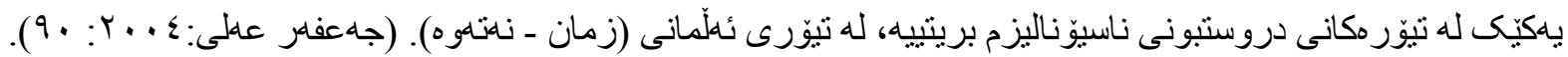

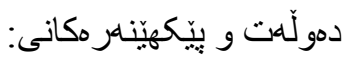

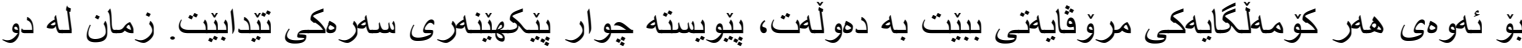

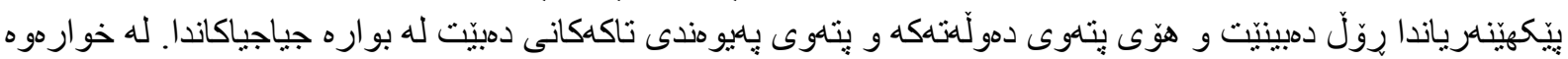
رونياندمكهينهوه:

خاك (ناوجهيهكى جوكر افى دياريكر او) Defined Derritory: 


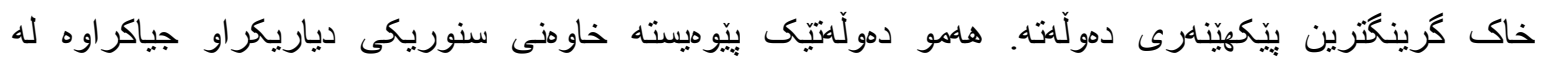
دموروبامر هكهى بيّت.

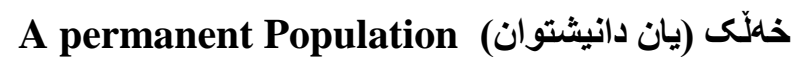

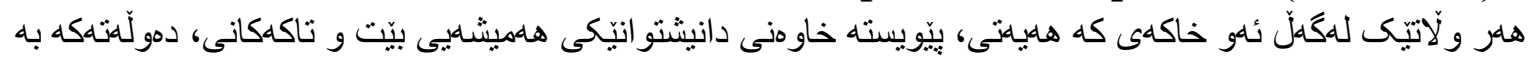

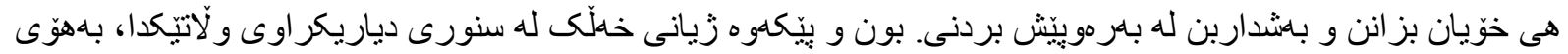

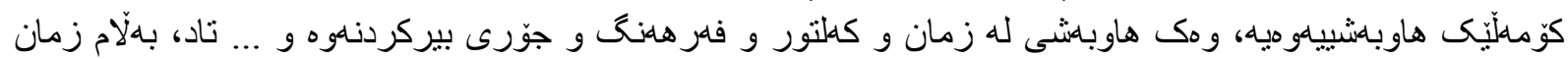

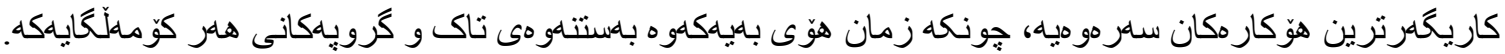

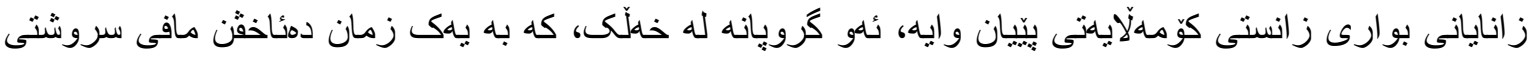

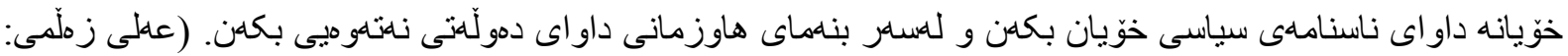

\section{حكومنت Government}

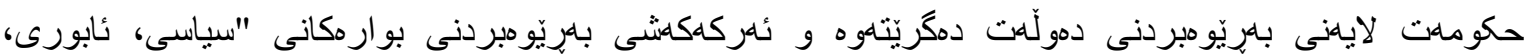

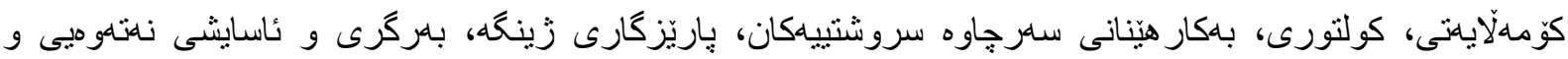

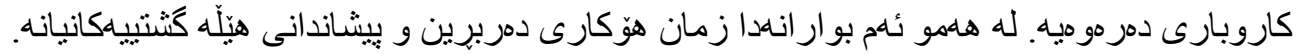

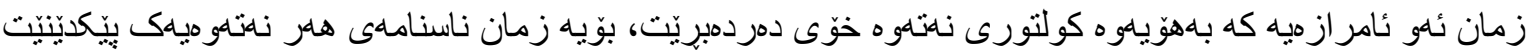

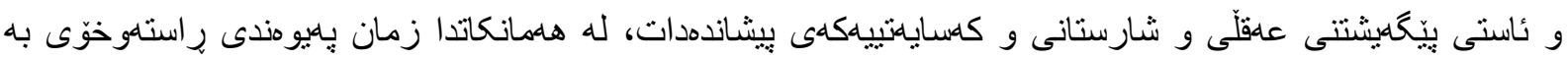

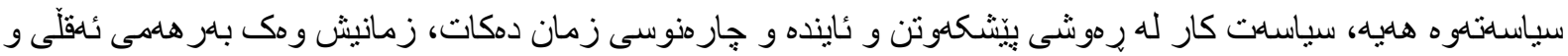

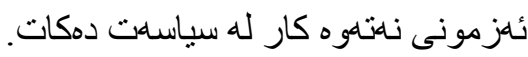

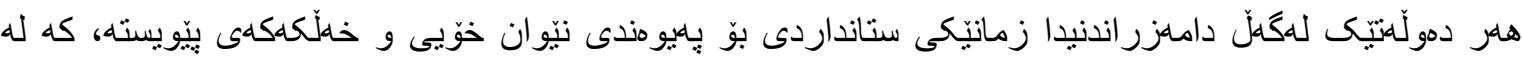

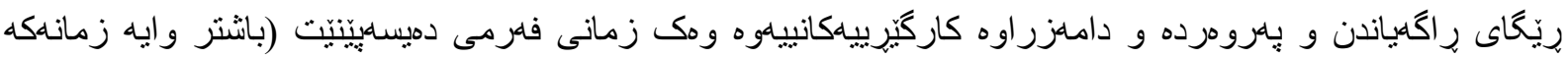

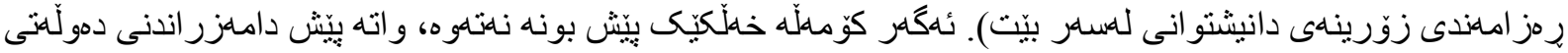

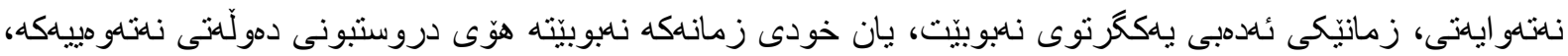

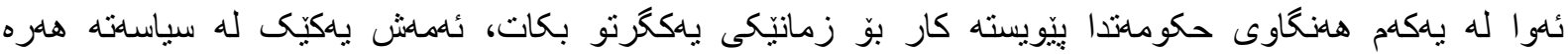

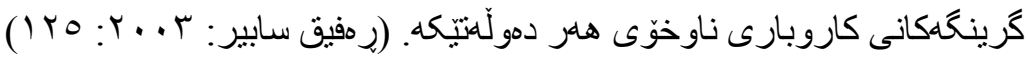

Sovereignty سلهروهرى

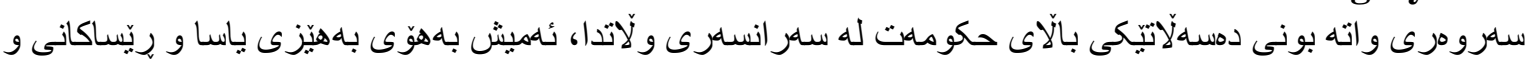

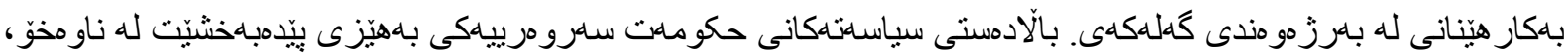

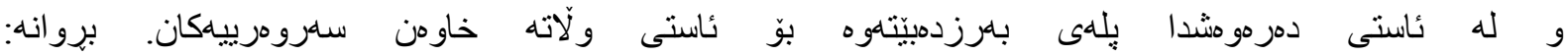
(theorybox.net/2010/03/4-elements-of-state)

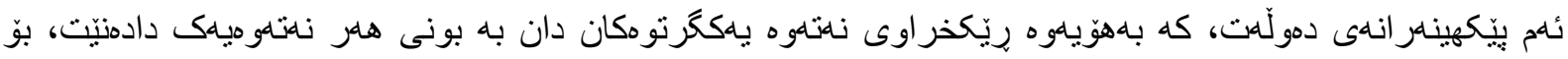

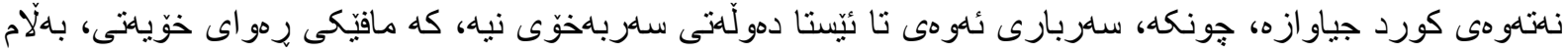

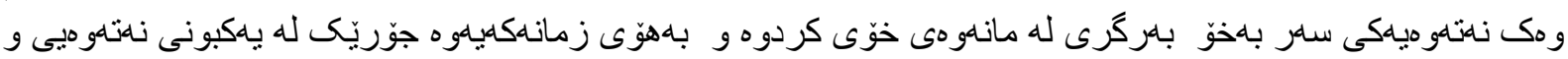

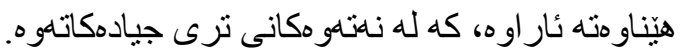


تايبهنييهكانى زمانى نلتتهوديى

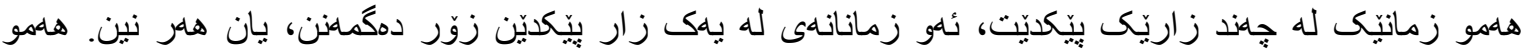

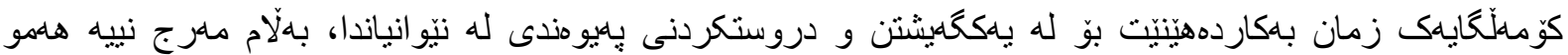

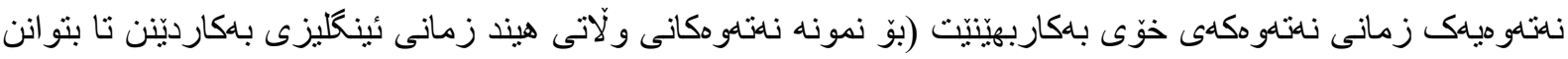

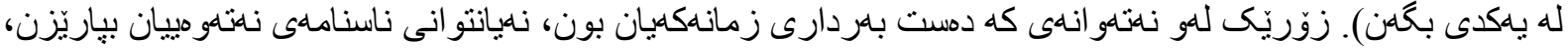

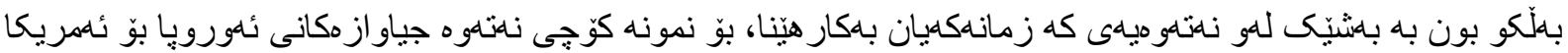

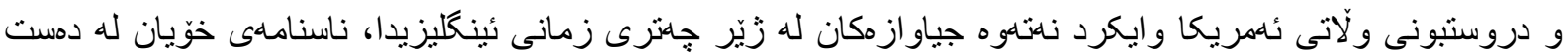

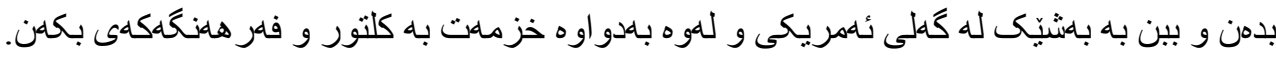

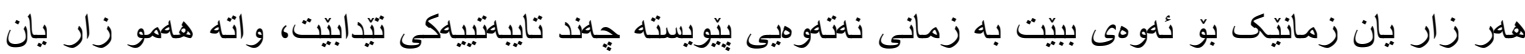

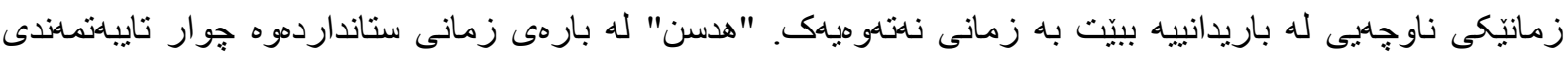

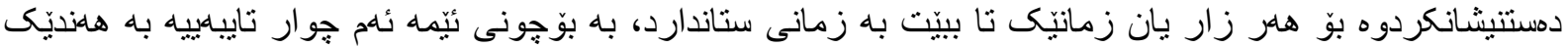

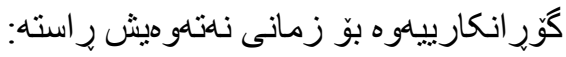

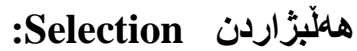

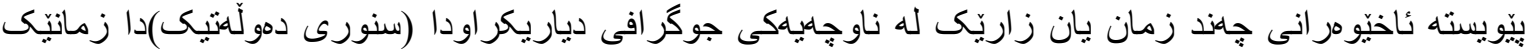

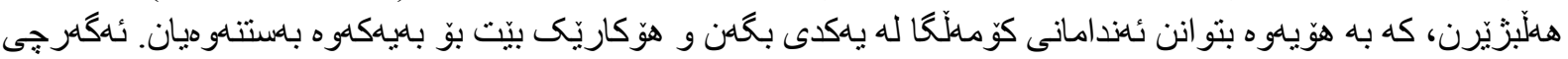

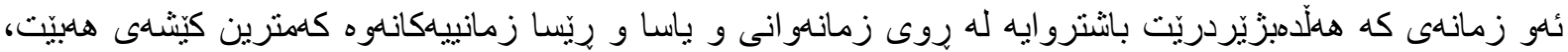

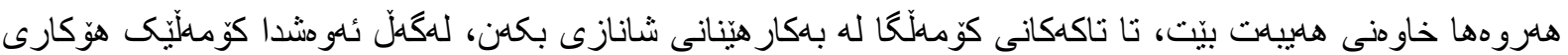

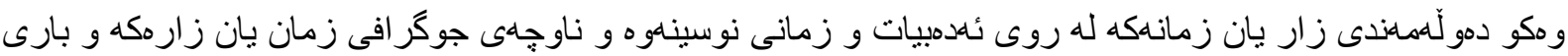

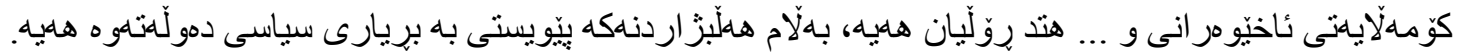

توَماركردن Codification

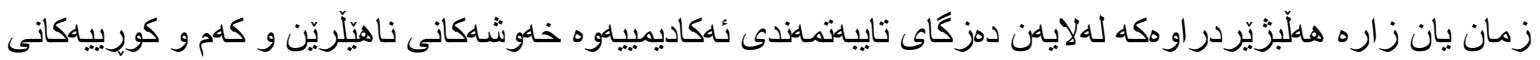

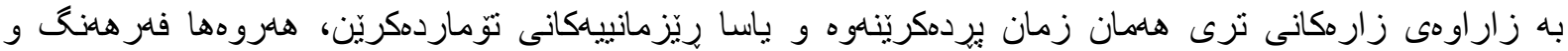

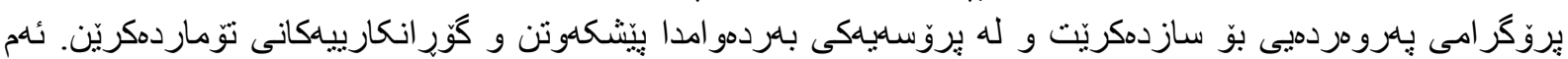

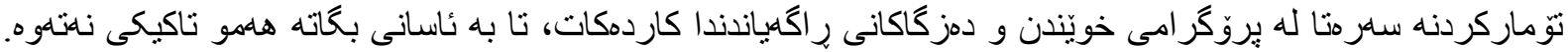

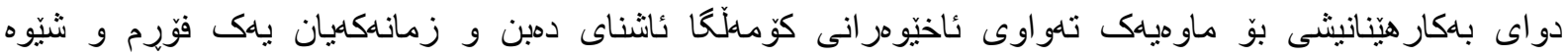
وهردمكريّت.

بوار فراوانكردن Elaboration of function:

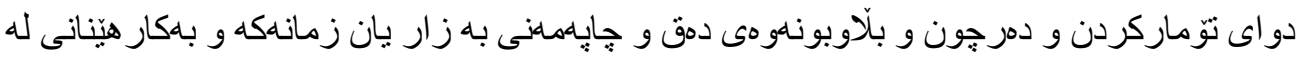

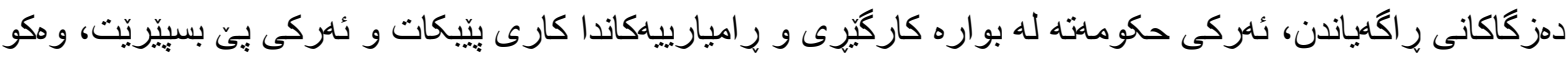

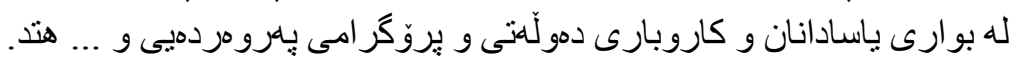




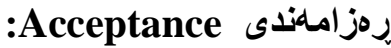

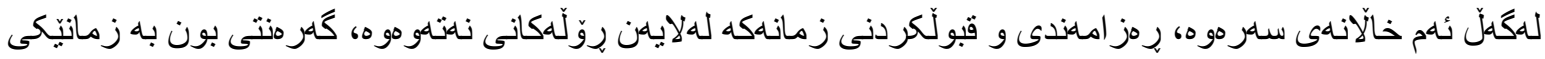

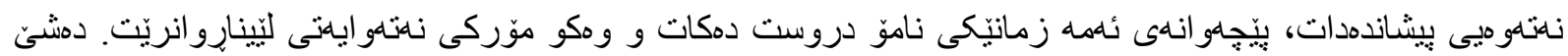

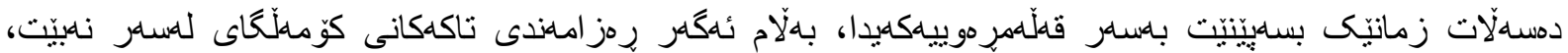

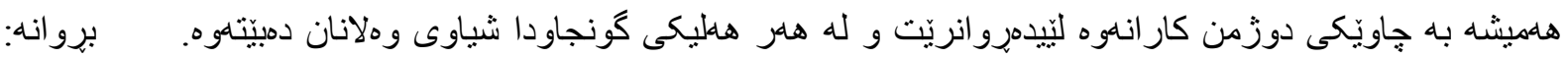

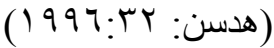

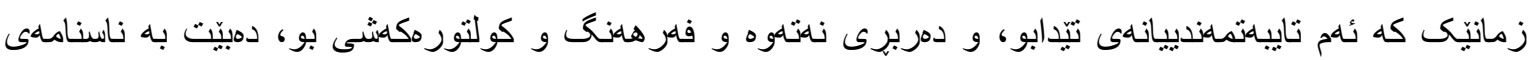

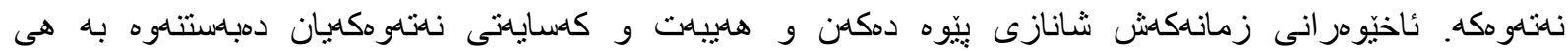

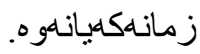

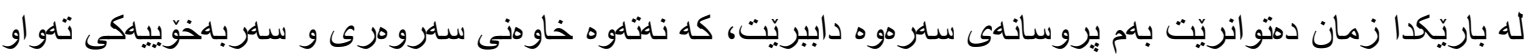

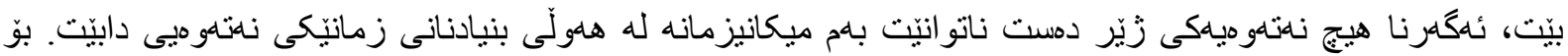

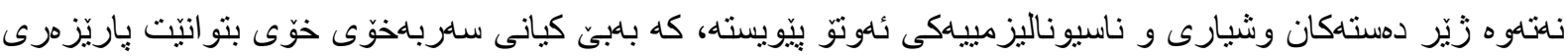

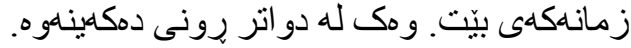

\section{بالشى دومم \\ زمانى دايك}

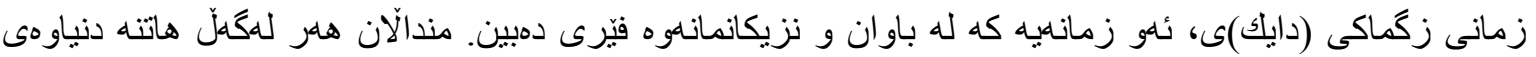

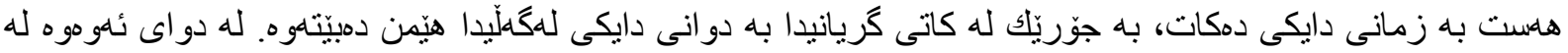

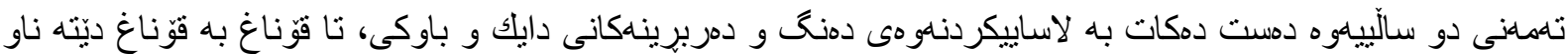

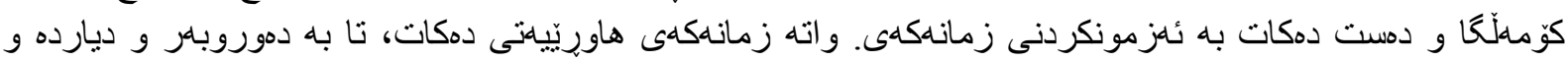

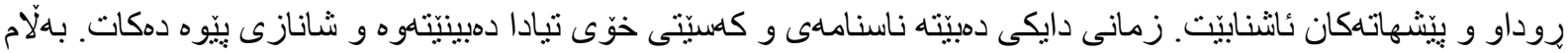

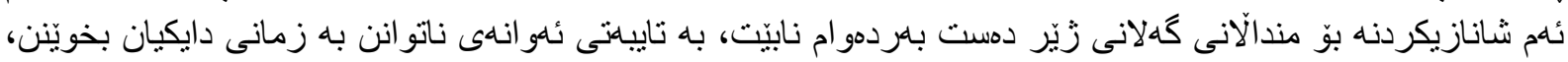

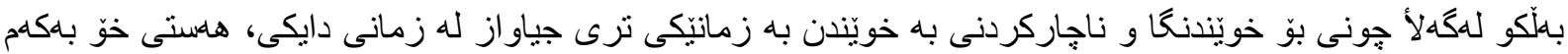

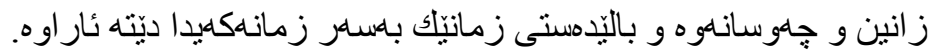

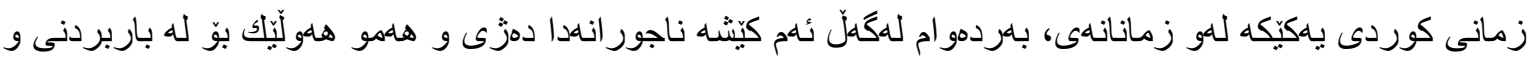

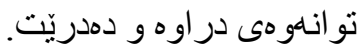

بيّيويستى زمانى دايك، بوّ كورد وهك هوَكارى مانهوه

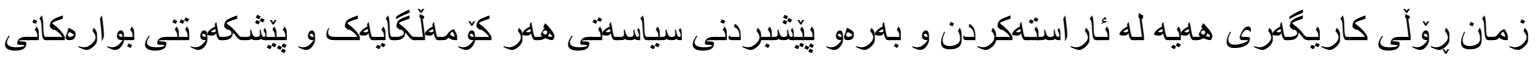

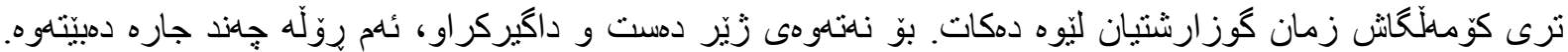

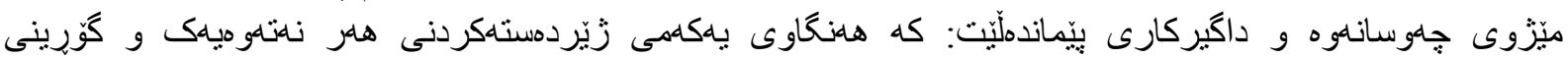

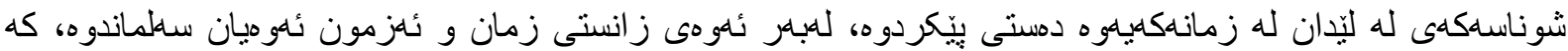

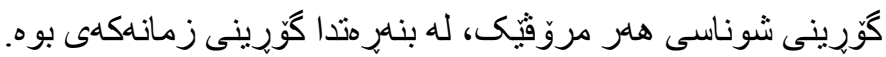




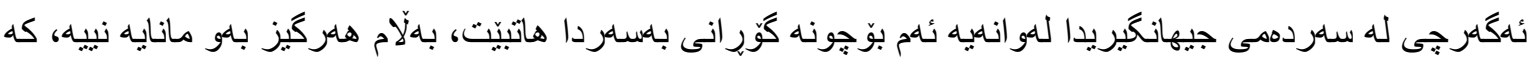

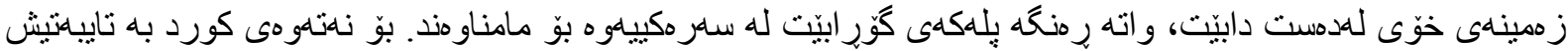

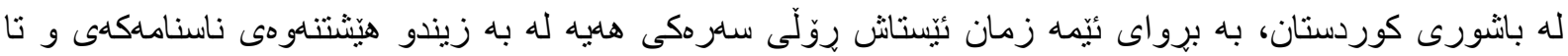

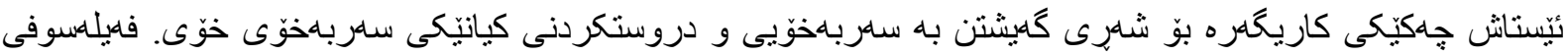

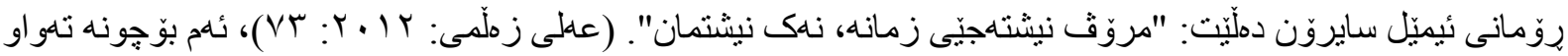

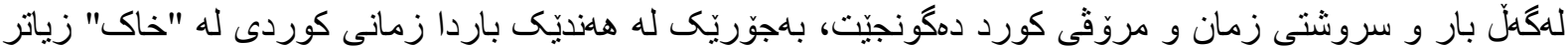

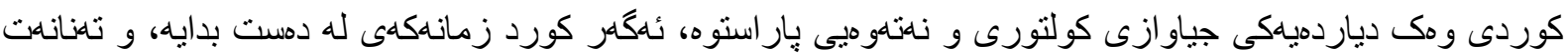

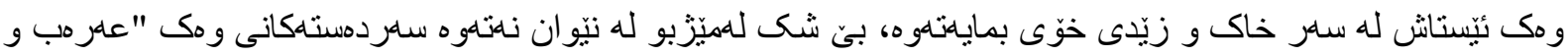

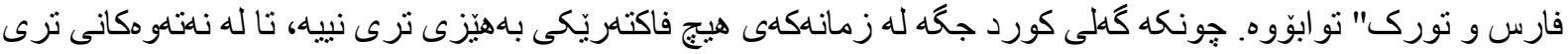

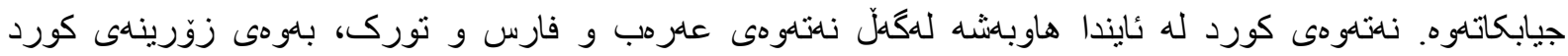

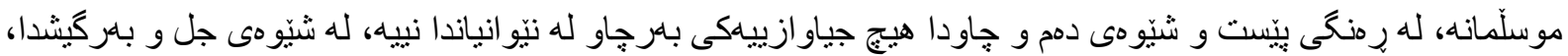

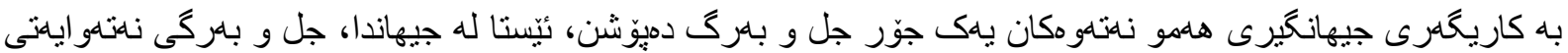

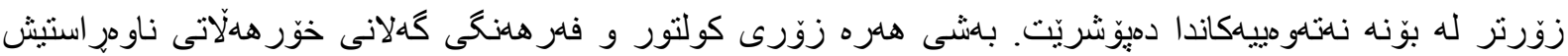

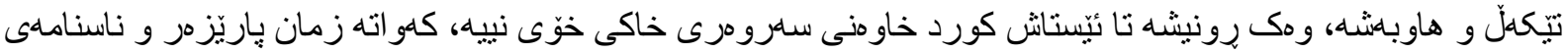

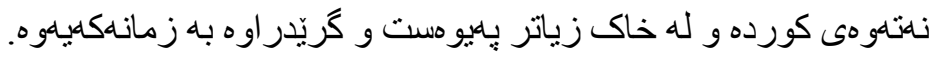

\section{نهتهوهى كورد و باككار هينانى زمانى دايك وهى مافيّكى گلهردونى}

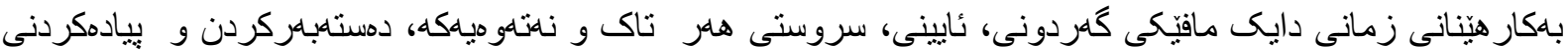

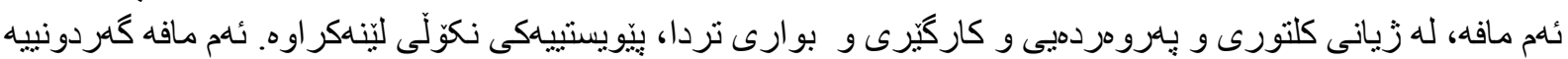

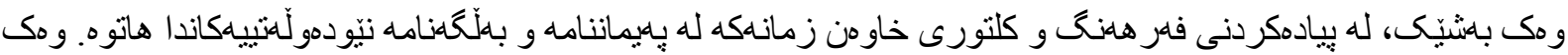

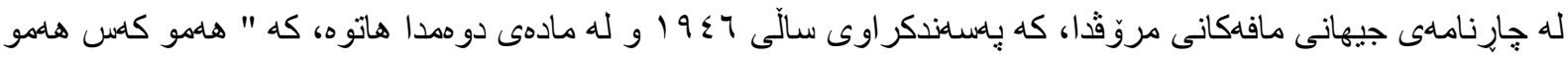

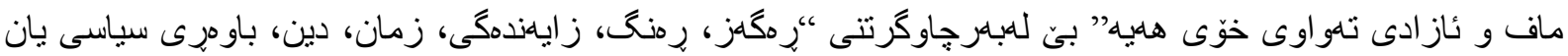

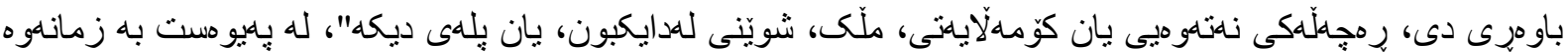

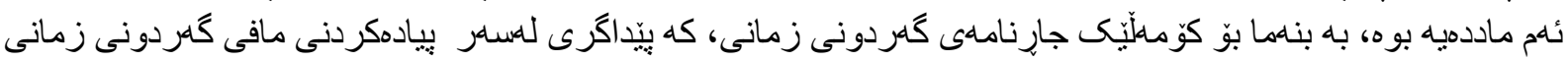

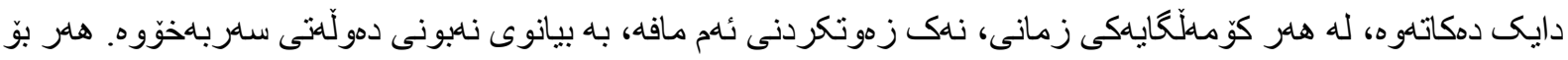

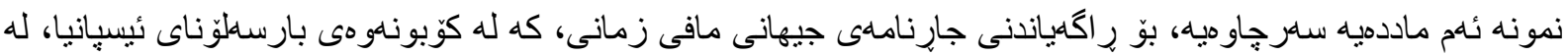

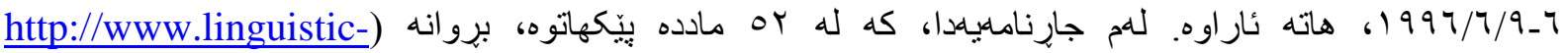

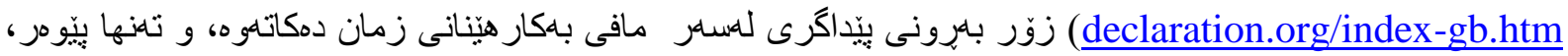

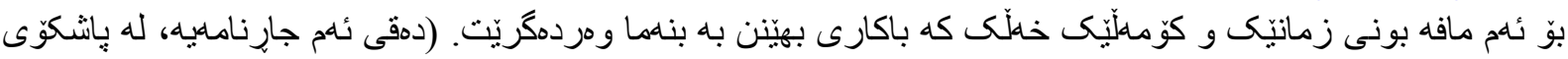
تويَزْينهو هكهدا هاتوه).

\section{مافى زمانى له نيّو دهستورى ولّاتان (جِهند ولّآتيّى به نمونه)}

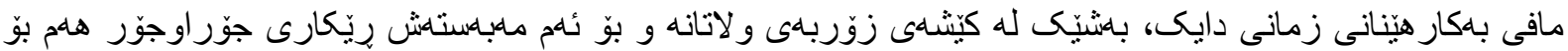

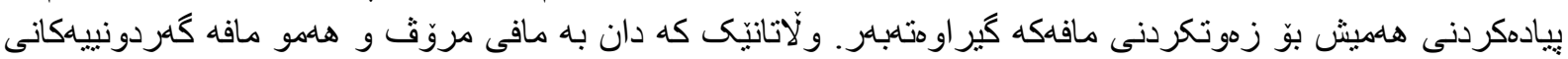

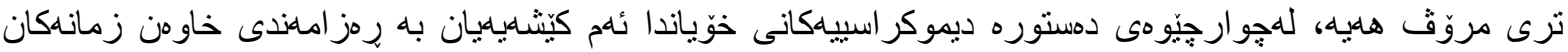

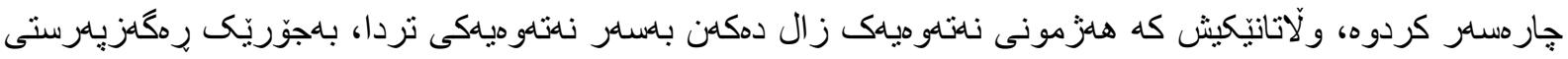




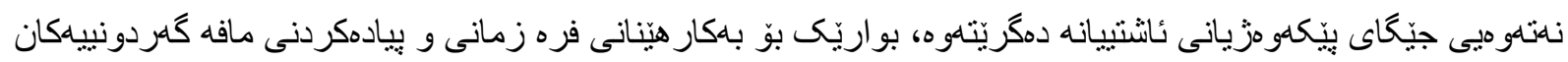

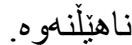

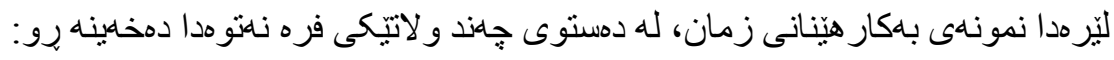

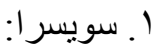

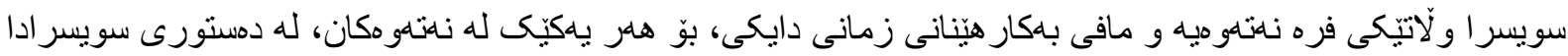

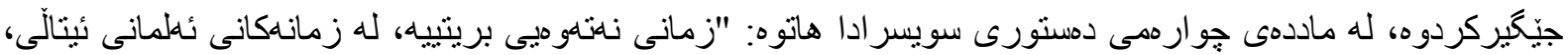

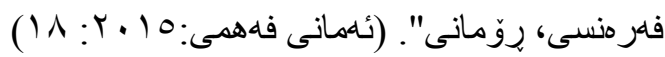

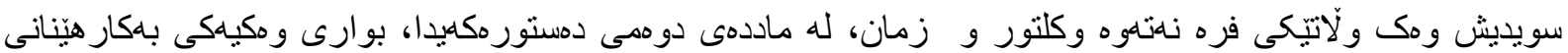

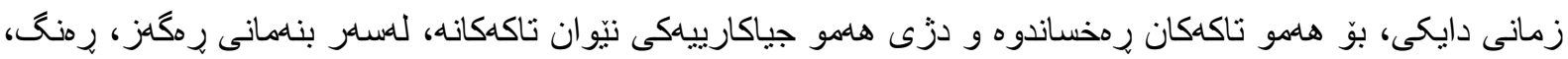

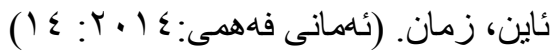

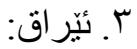

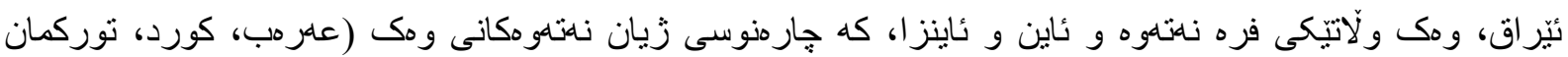

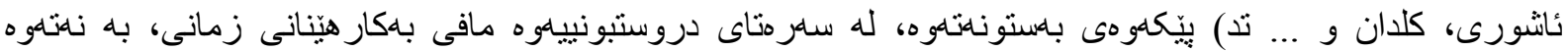

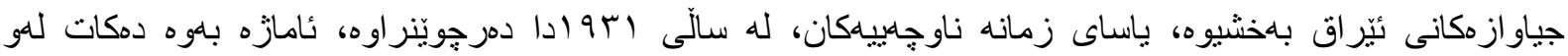

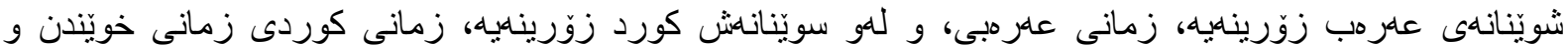

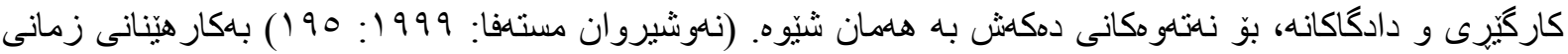

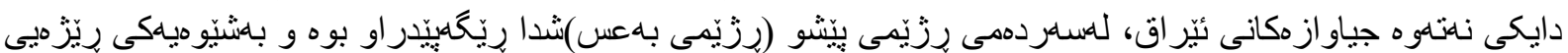
بيادمكر اوه.

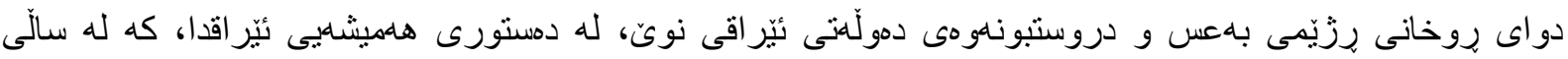

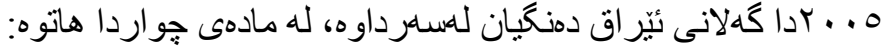

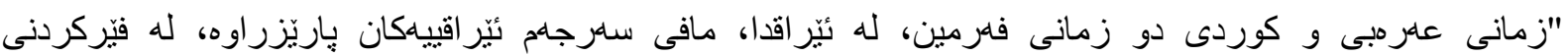

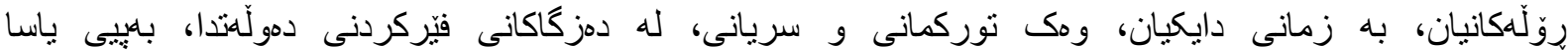

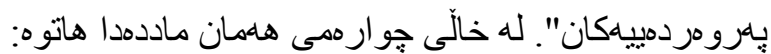

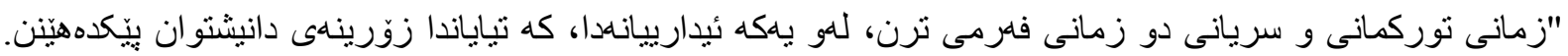

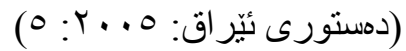

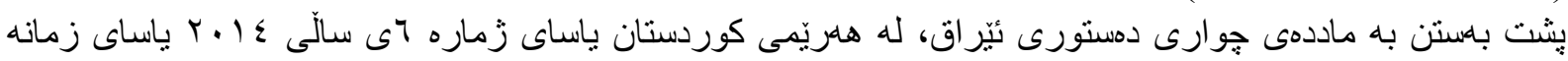

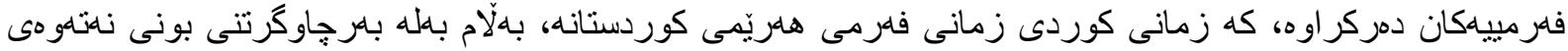

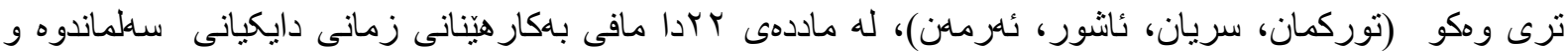

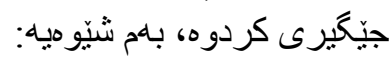

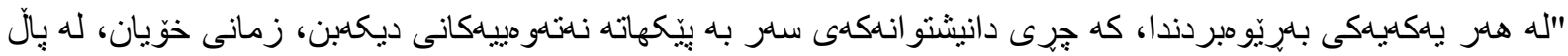

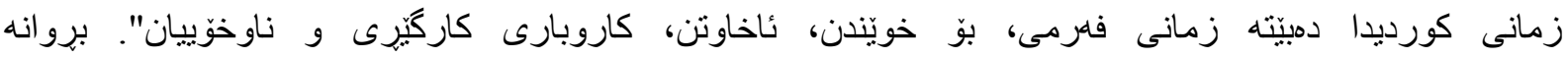
(http://www.perleman.org/files/articles/141214061821.pdf) 


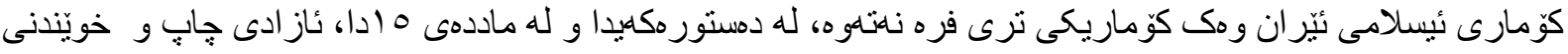

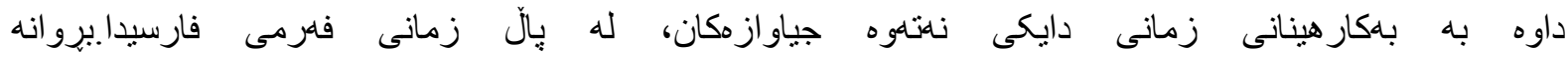
(file:///C:/Users/Brwa/Downloads/ghanoonasasi.pdf)

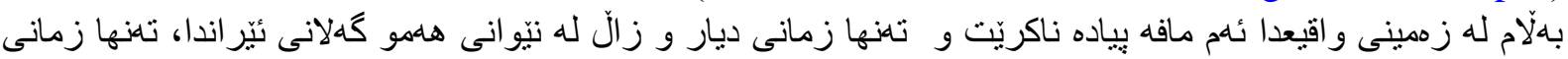
فارسياه.

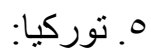

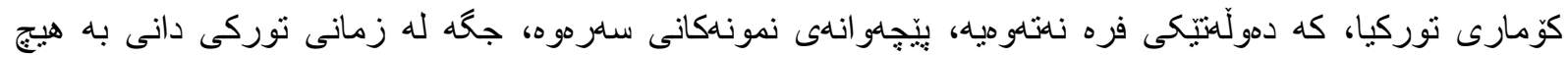

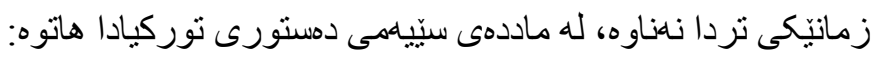

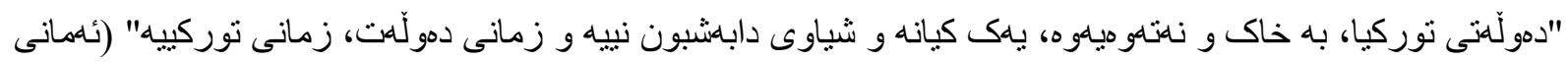

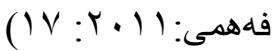

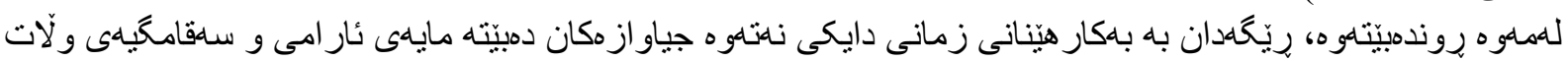

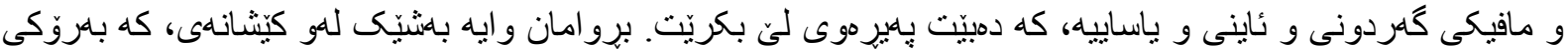

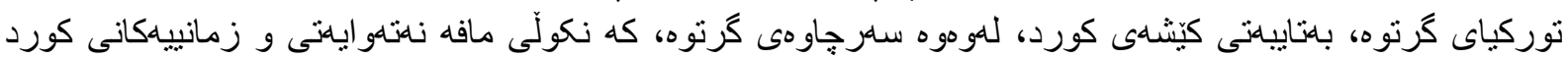

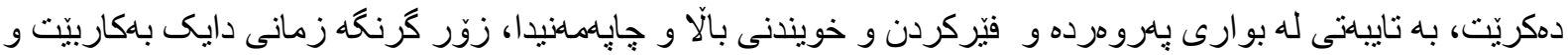

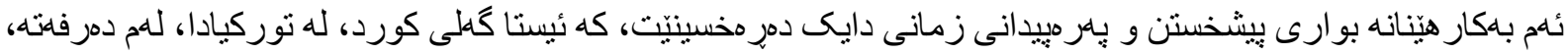

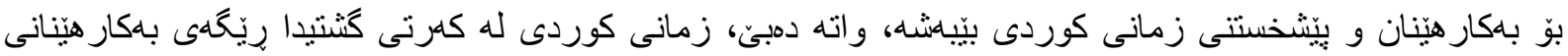

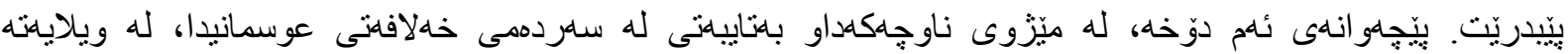

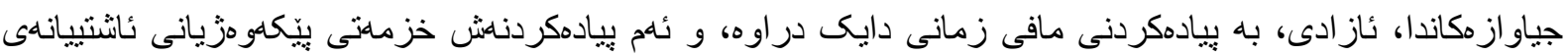

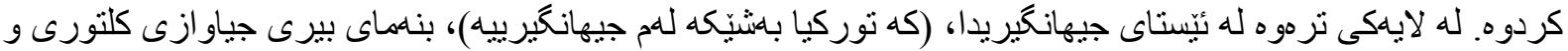

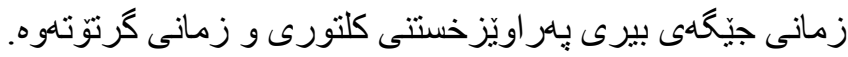

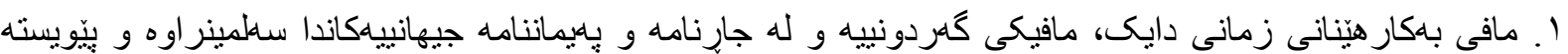

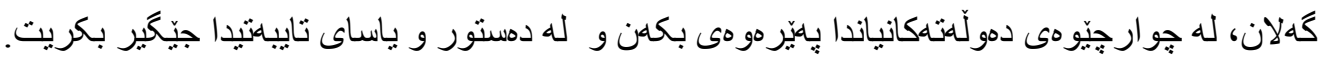

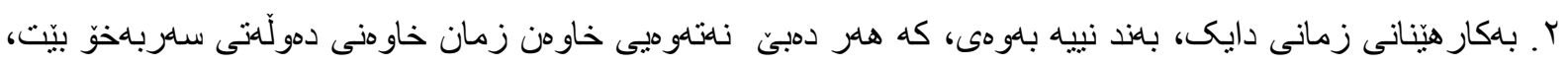

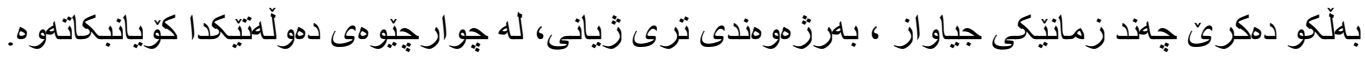

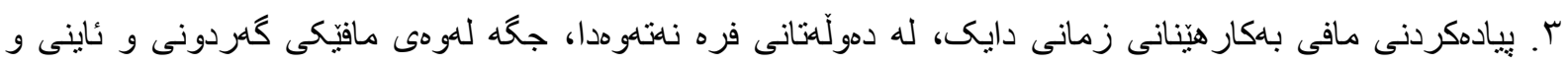

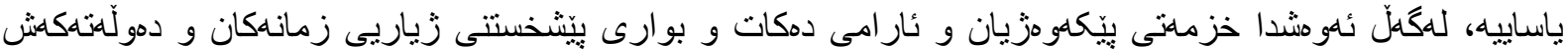

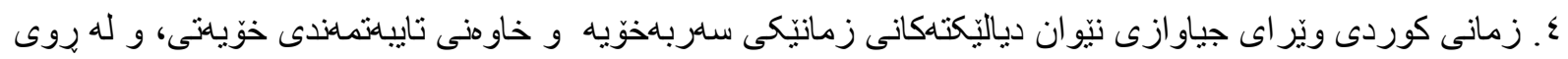

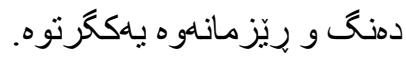

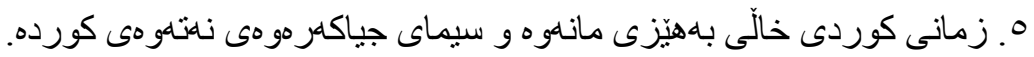




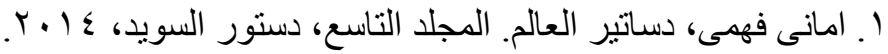

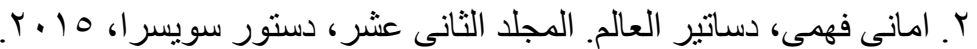

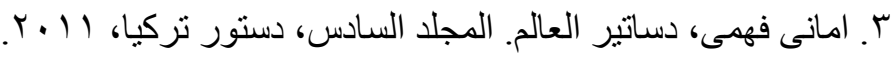

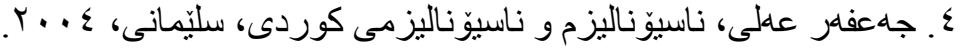

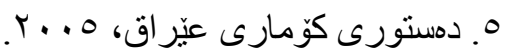

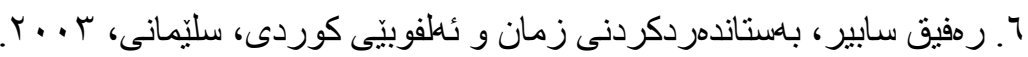

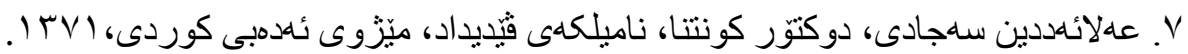

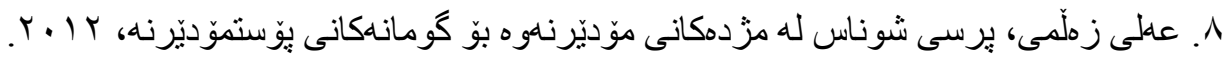

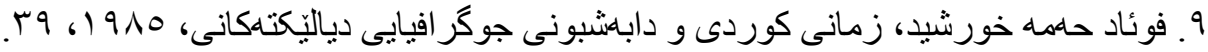

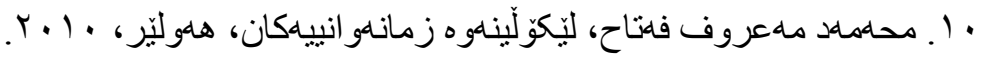

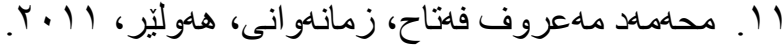

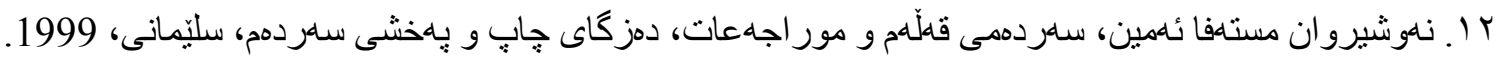

13. Hudson R.A., Sociolinguistics, 1996, Cambridge. 14. http://www.perleman.org/files/articles/141214061821.pdf

15. file:///C:/Users/Brwa/Downloads/ghanoonasasi.pdf

16. http://www.linguistic-declaration.org/index-gb.htm theorybox.net/2010/03/4-elements-of-state.17. http://www

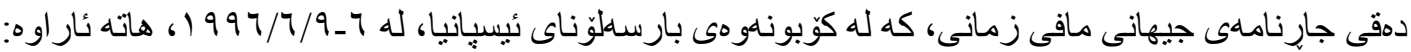

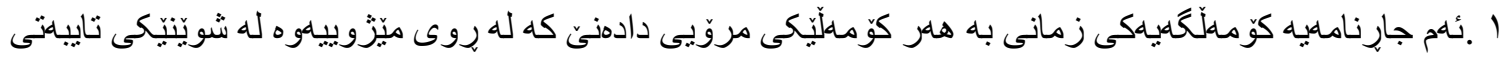

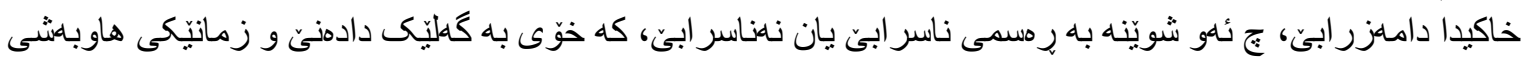

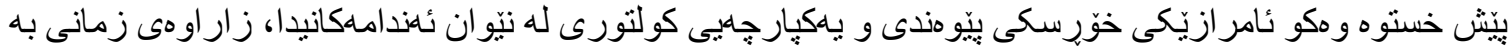

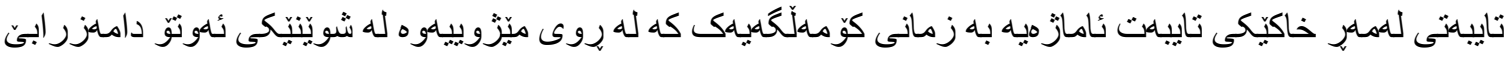

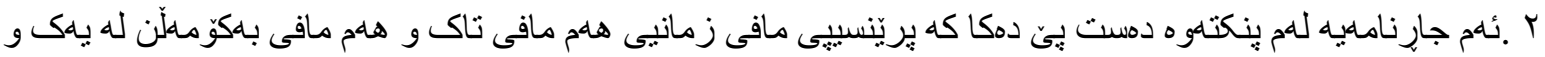

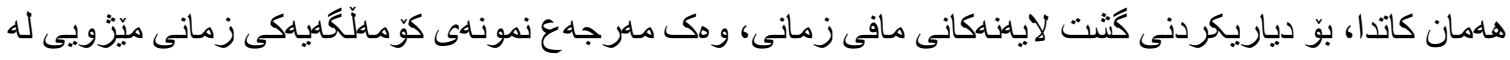

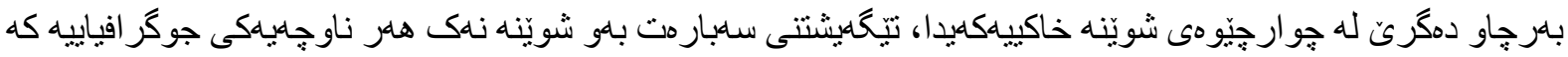

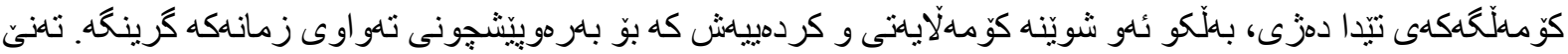

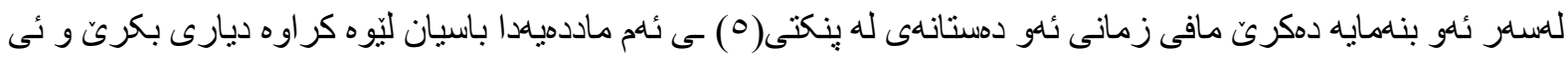

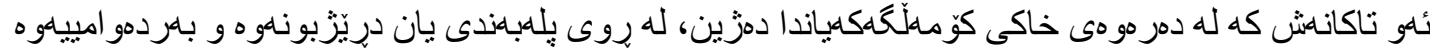

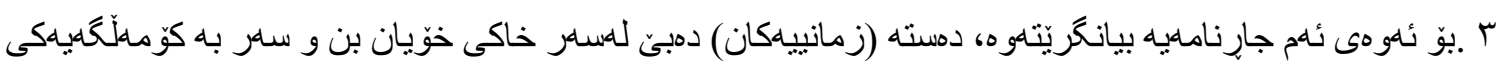

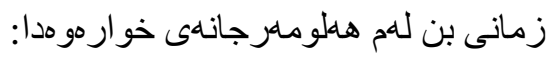




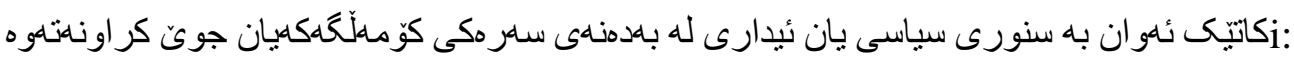

iii: دابن، يان

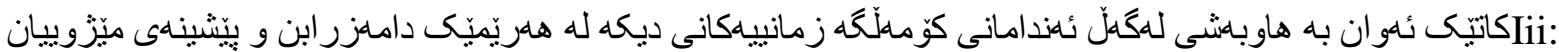

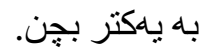

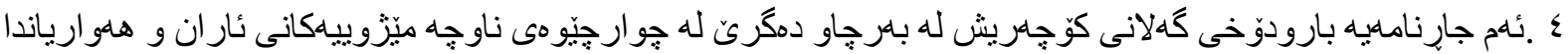

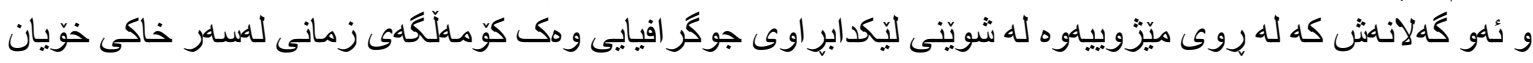
دمزين.

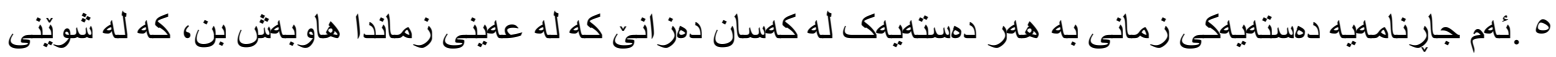

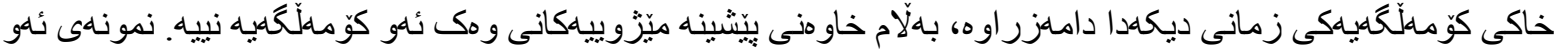

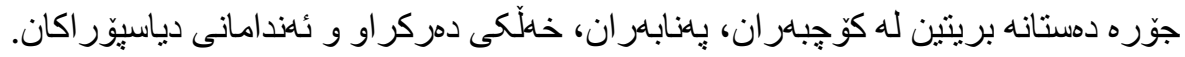

r مادمى

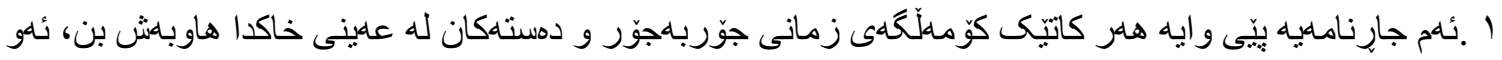

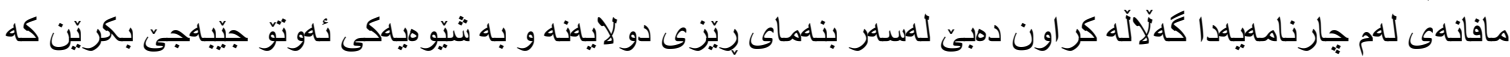

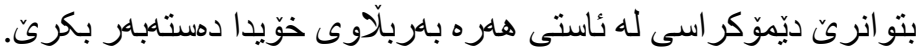

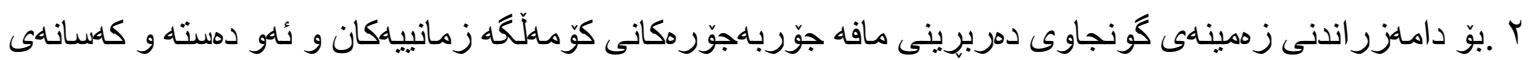

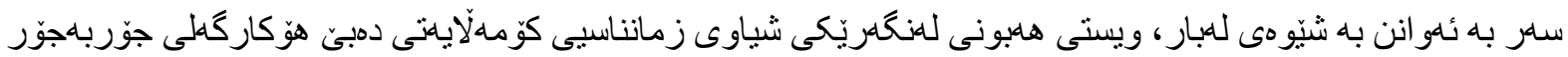

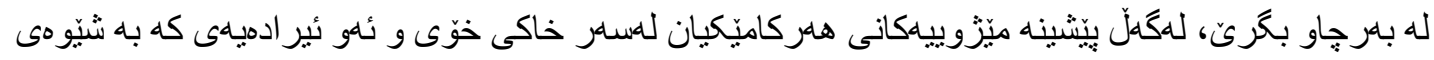

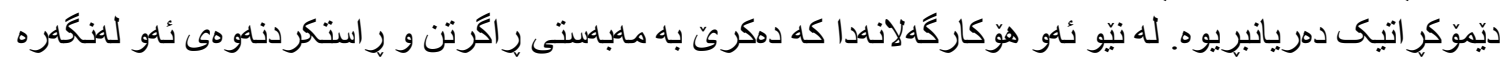

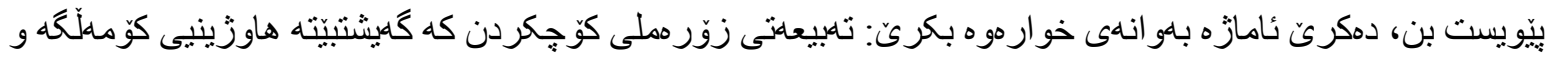

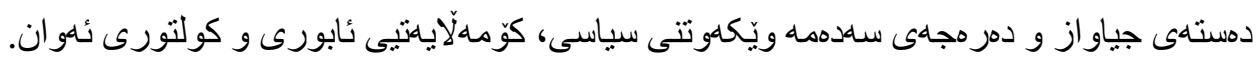

r. Hمادمى*

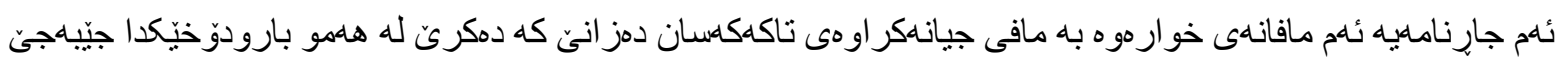
بكريّن.

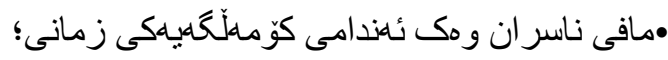

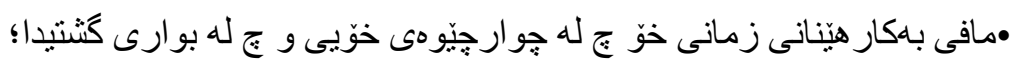

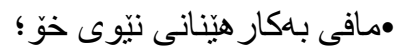

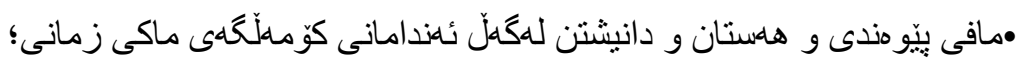

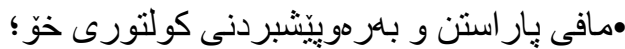

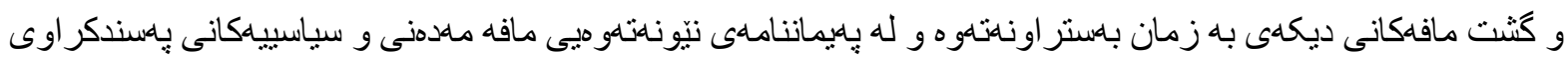

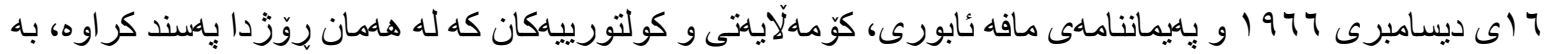

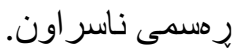

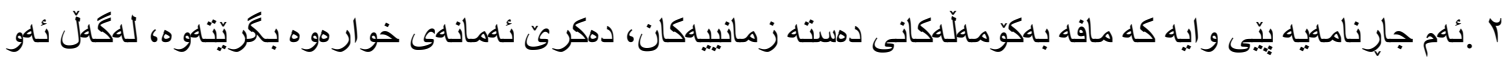

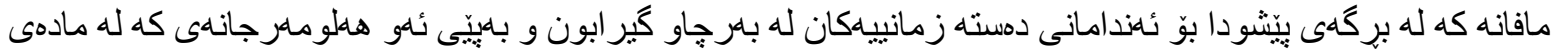

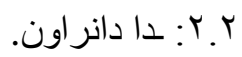

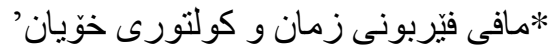

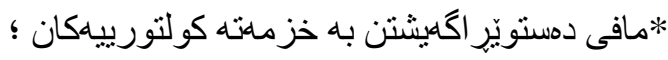

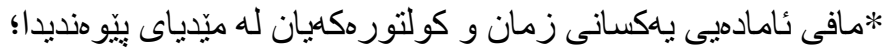




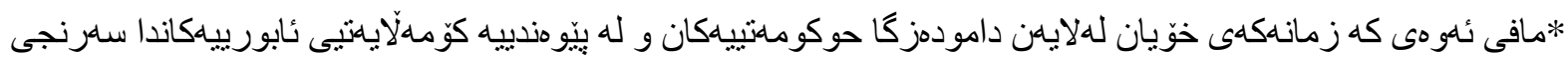
بدريَتىّ.

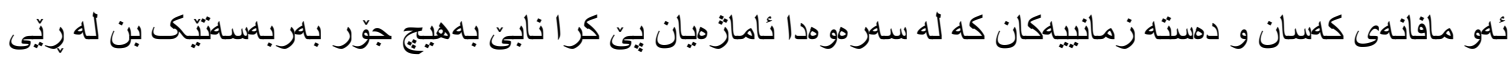

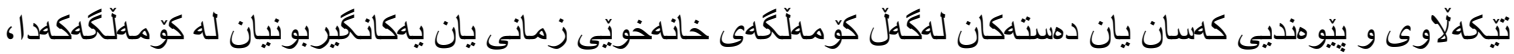

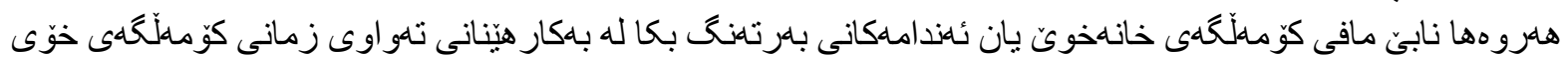

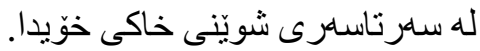

¿مادمى

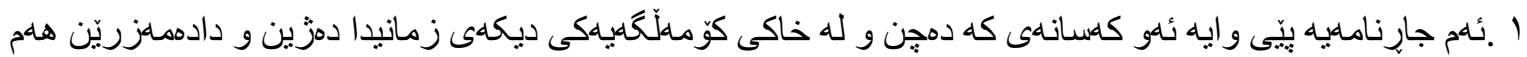

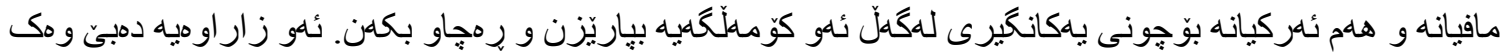

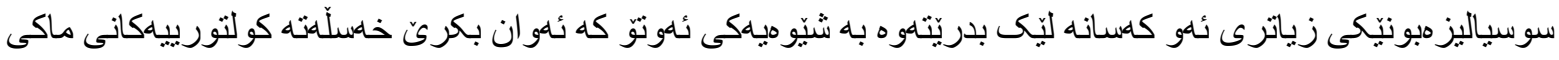

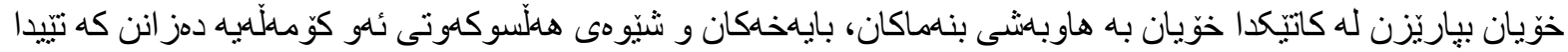

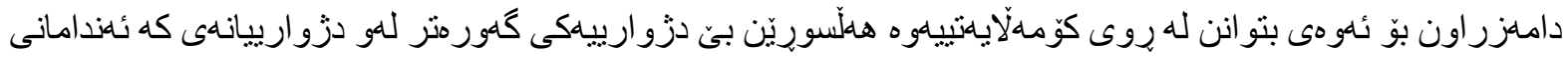

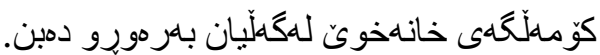

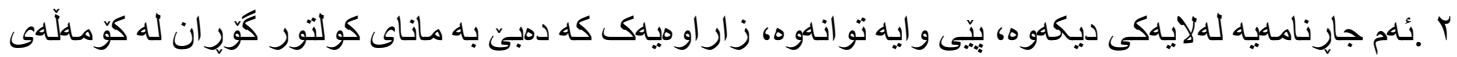

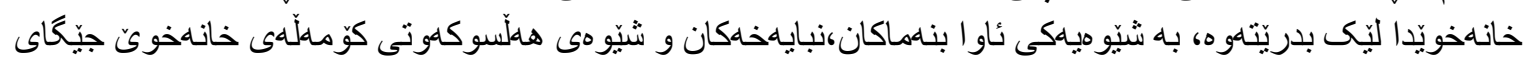

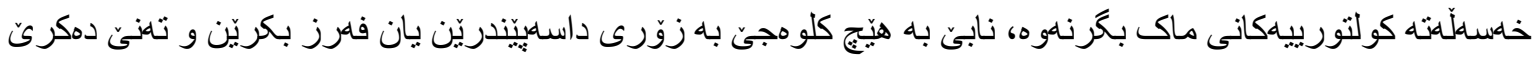
ئاكامى برياريّكى تناو او ئاز اد بن. مان.

مادمى

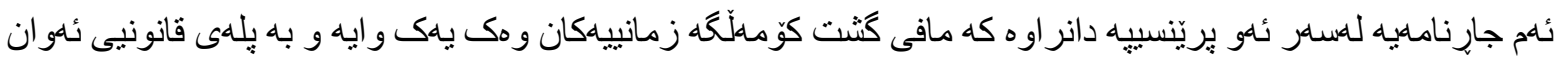

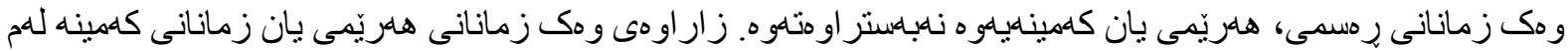

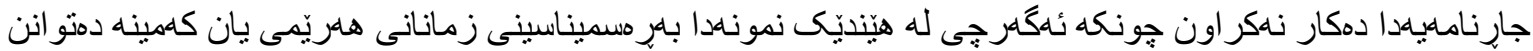

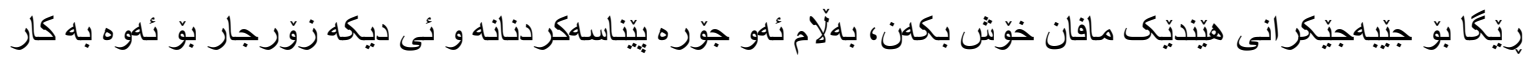

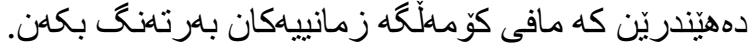

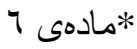

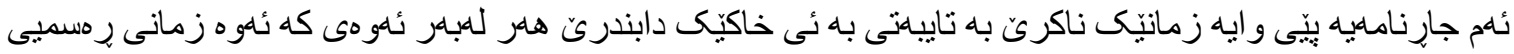

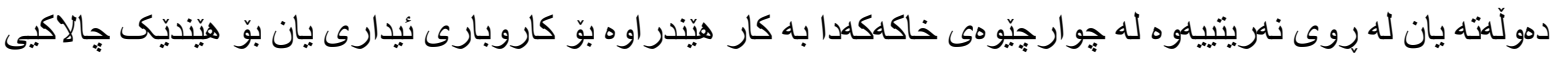
كولتورى.

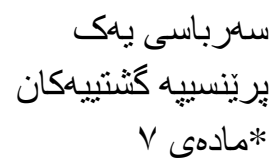

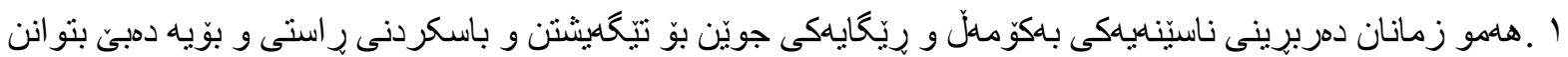

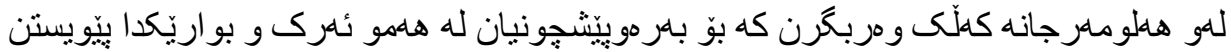

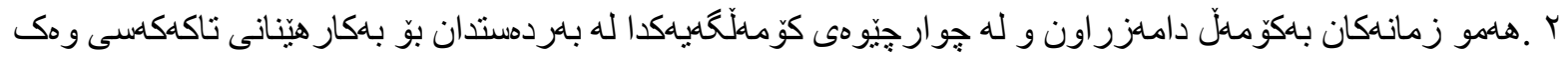

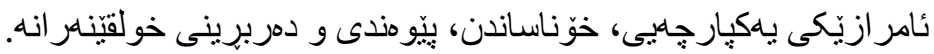

1مادمى

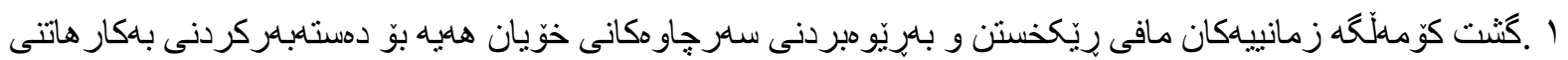

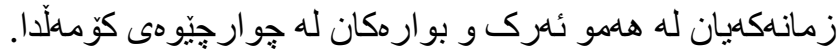

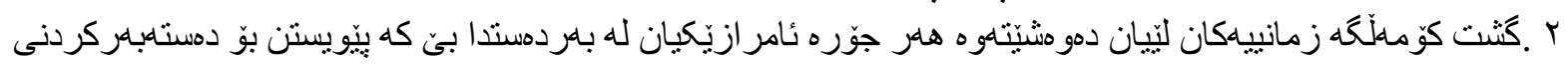

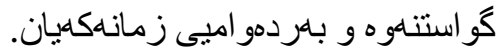


9 مادمى 9

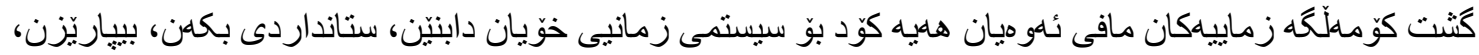

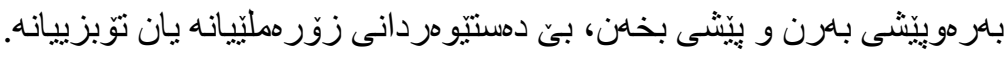

1. مادهى *

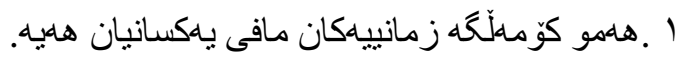

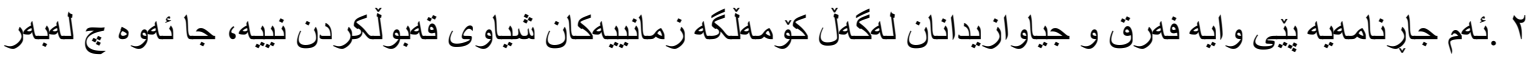

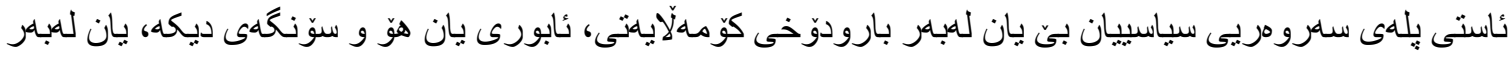

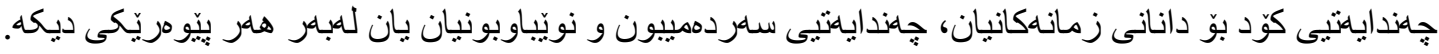

11 مادم:

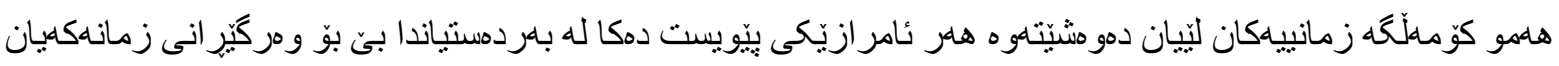

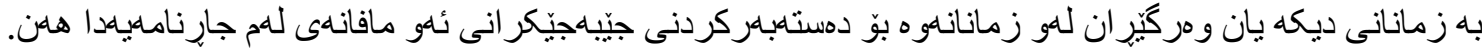

مادos*

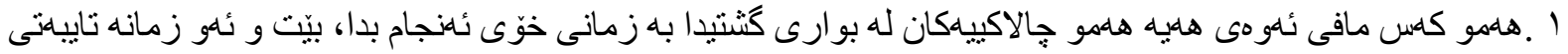

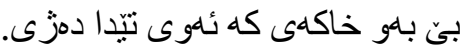

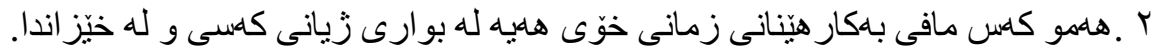

IT مادمى

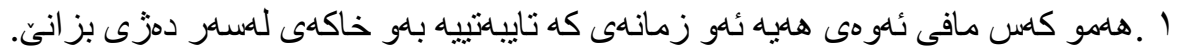

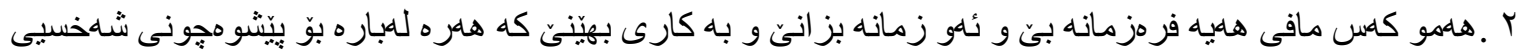

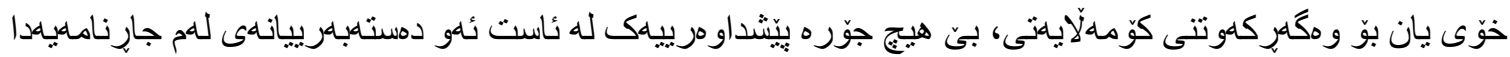

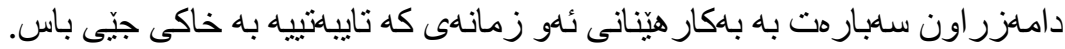

مادهى 1 \&

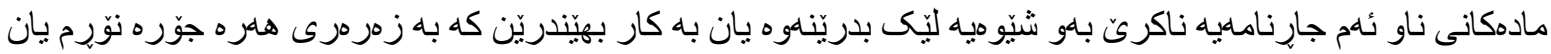

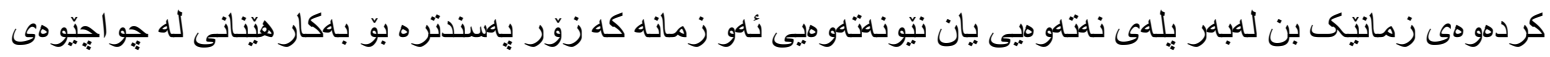

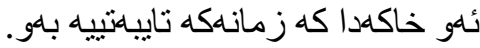

$$
\begin{aligned}
& \text { سارب باسى دو هلمج }
\end{aligned}
$$

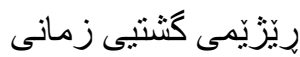

$$
\begin{aligned}
& \text { بانشى } 1
\end{aligned}
$$

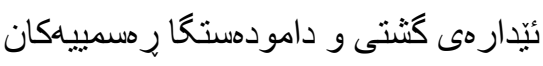

$$
\begin{aligned}
& \text { مادهى } 10 \text { * ماركى }
\end{aligned}
$$

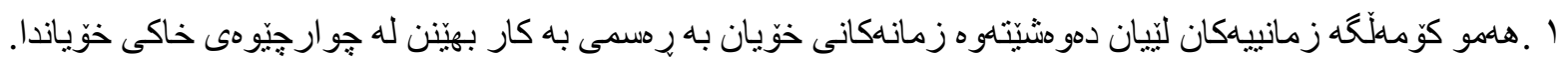

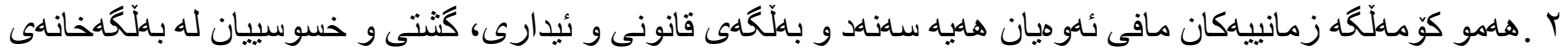

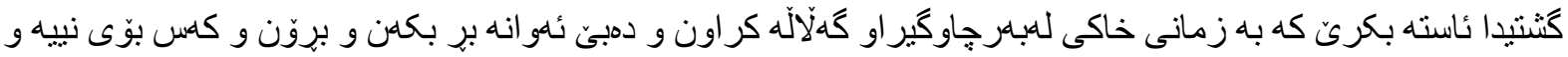

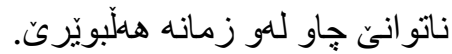

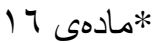

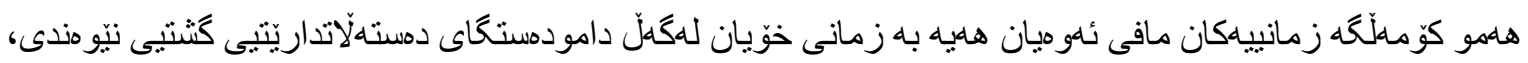

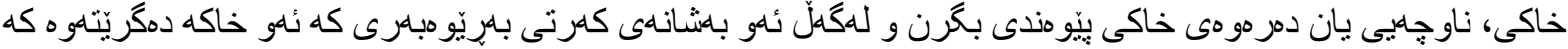

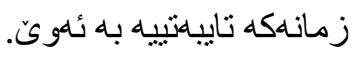


IV مادهى*

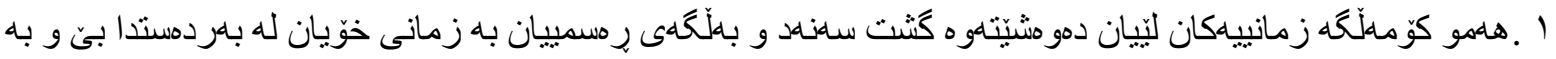

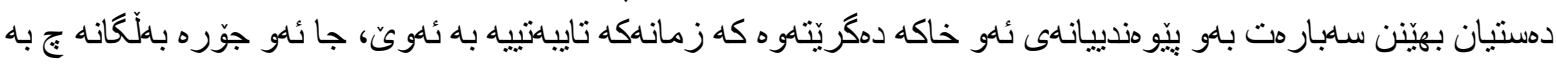

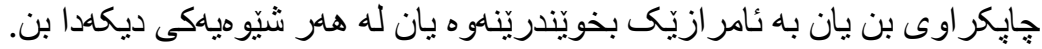

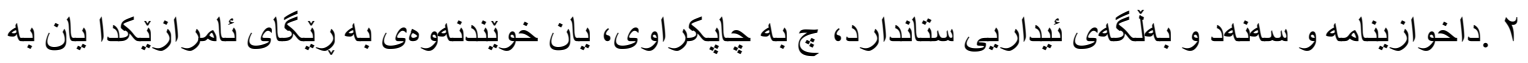

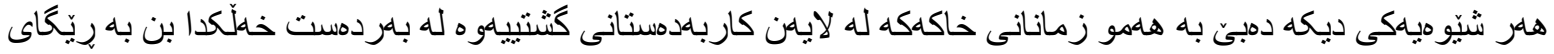

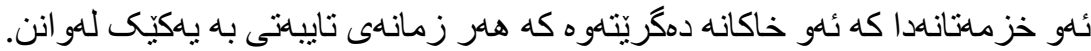

11 مادoى*

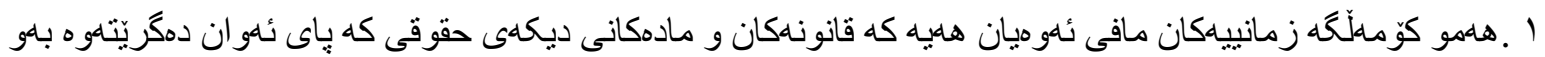

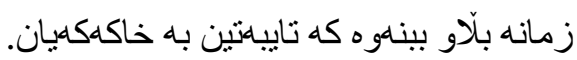

19 مادم:

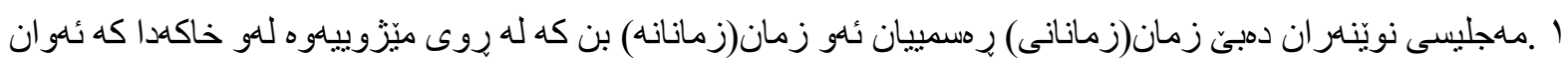

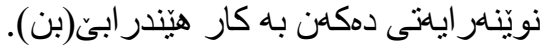

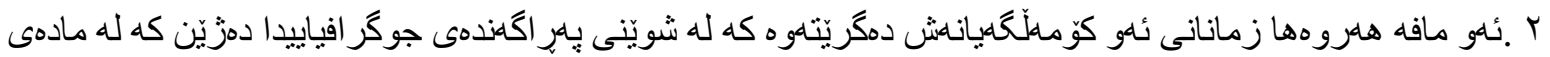

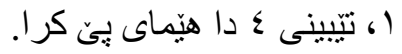

r. مادى*

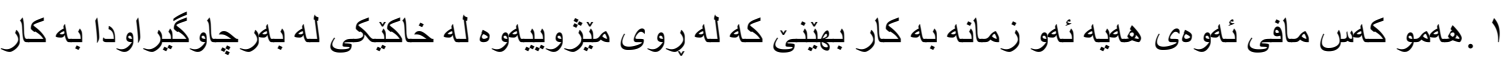

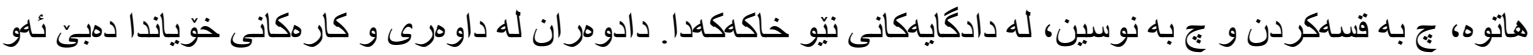

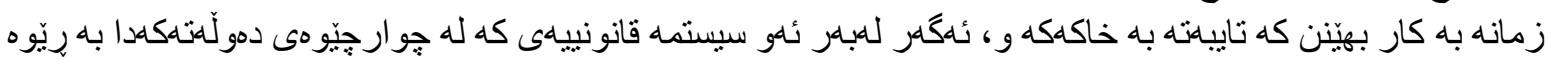

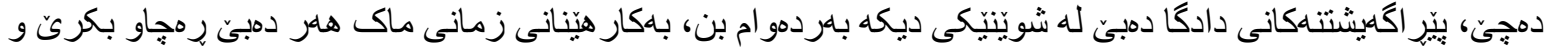
بياريَزْرَّ.

Y) مادم: S*

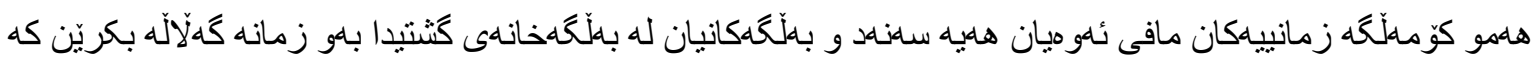

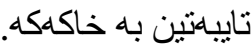
rr مادم

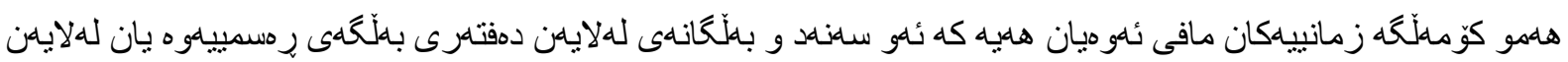

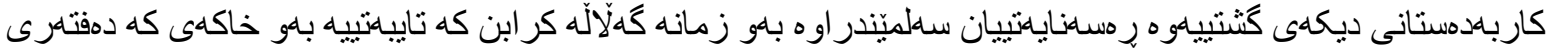

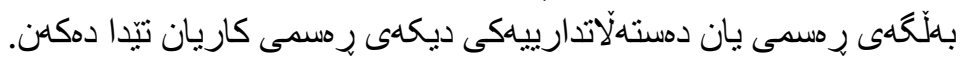

$$
\begin{aligned}
& \text { باهثى } \\
& \text { يهرو برده }
\end{aligned}
$$

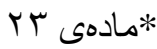

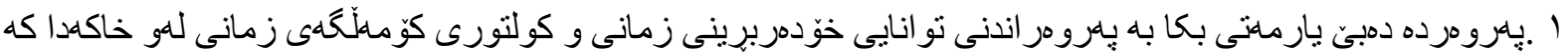
دابين دمكرى دون.

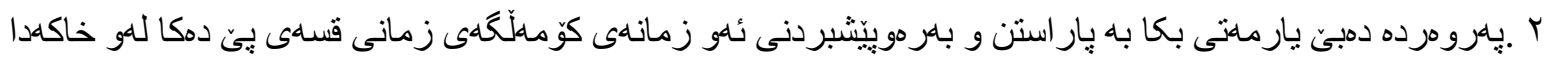
كه دابين دهكرى.

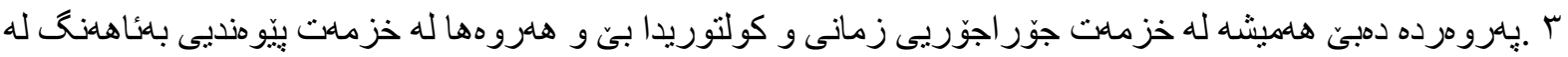

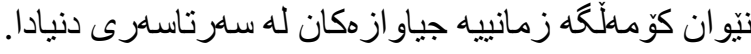


Y 5 S

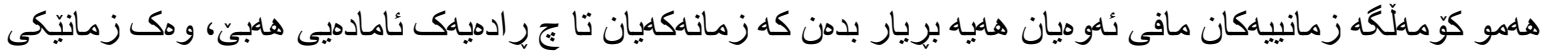

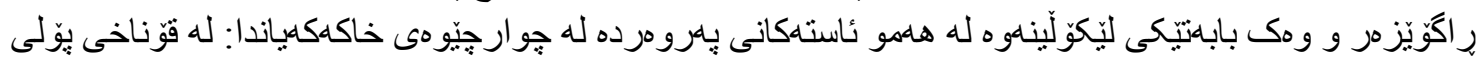

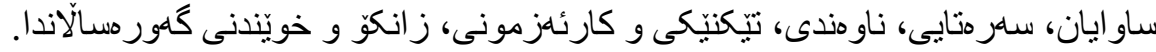

Yo مادoى*

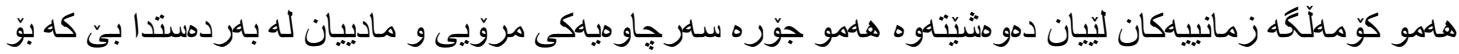

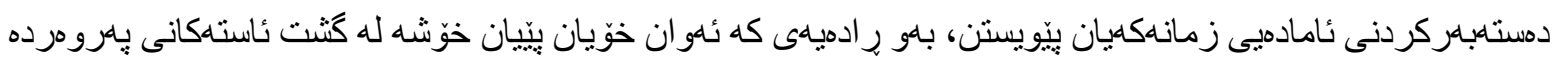

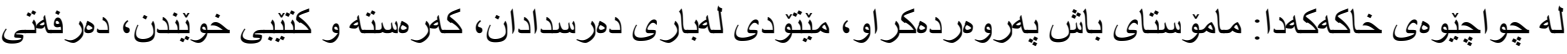

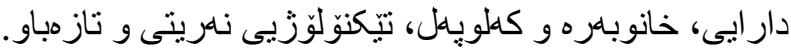

rT مادمى

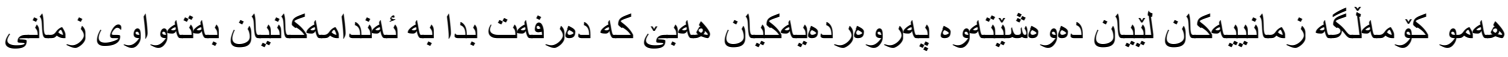

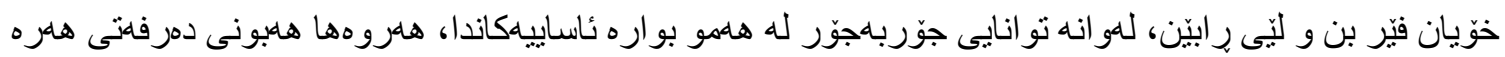

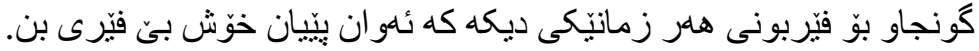

rV مادهى*

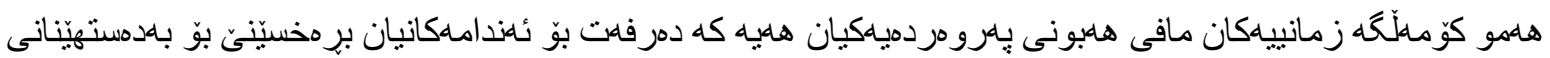

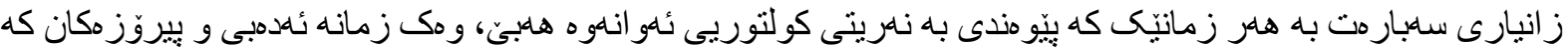

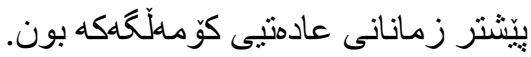

rᄉ مادم:

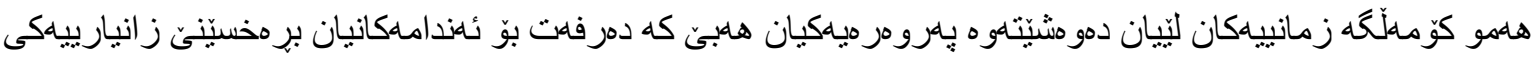

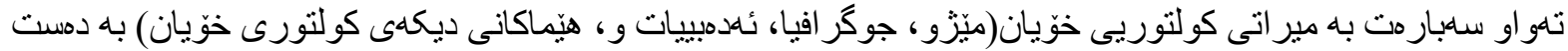

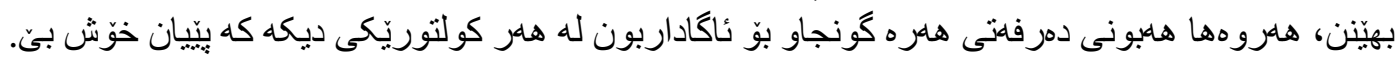

r مادهى 9

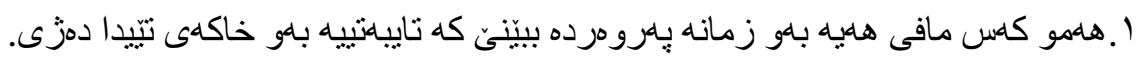

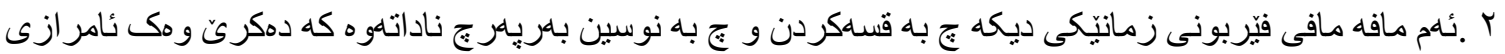

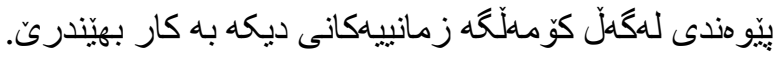

r. مادهى

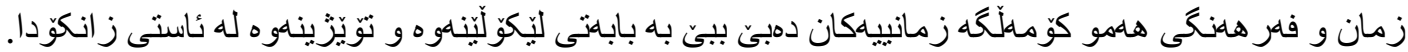

$$
\begin{aligned}
& \text { نبانشى } \\
& \text { ناوى تايبينتى }
\end{aligned}
$$

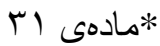

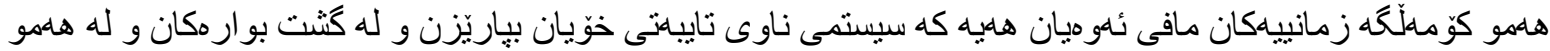
بوّنهيهكدا بـه كاريان بهيّن.

rre

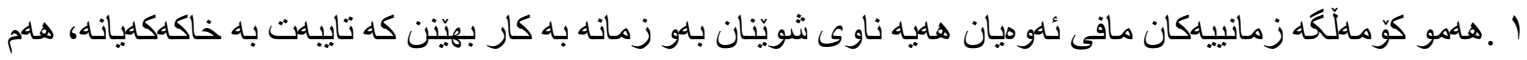

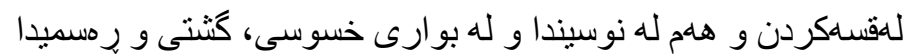

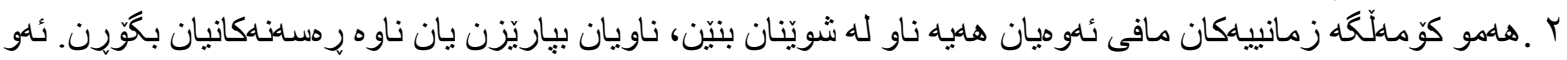




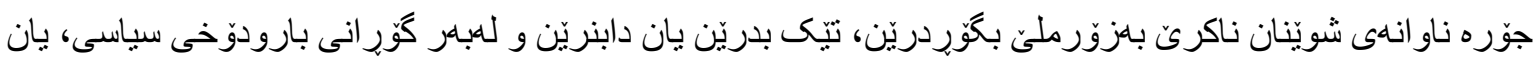

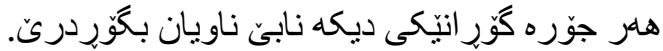

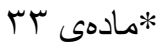

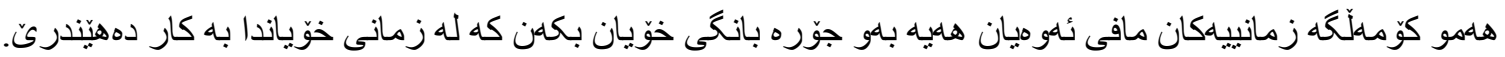

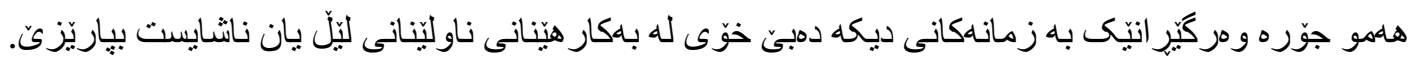

r مادهى

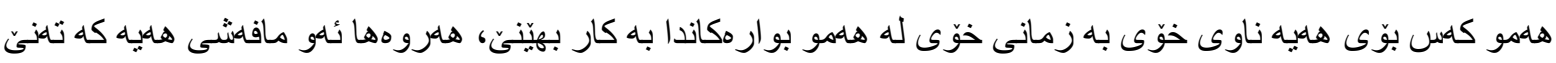

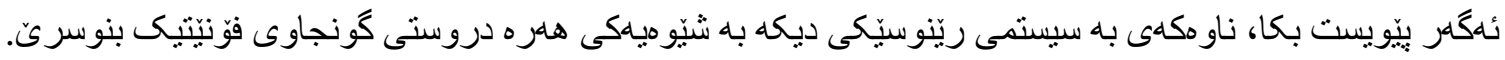

IV بانشى

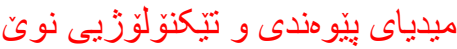

ro مادهى

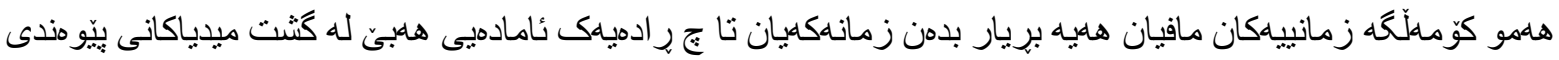

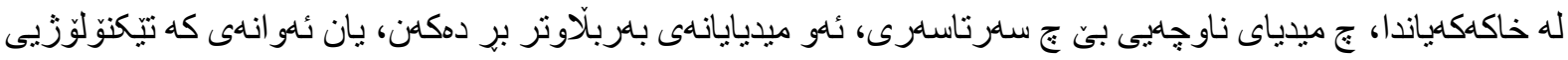

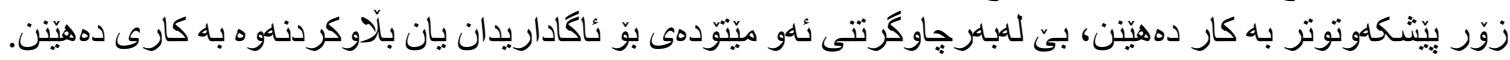

مادهى Tr*

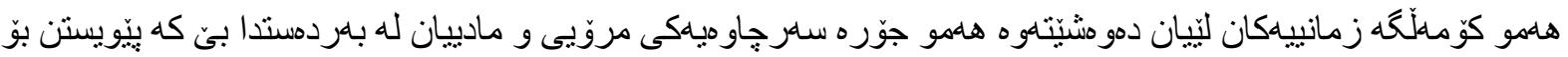

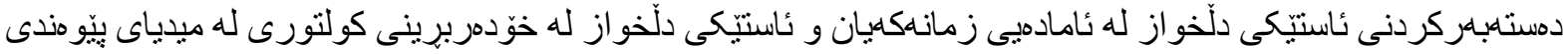

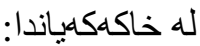

rV مادهى

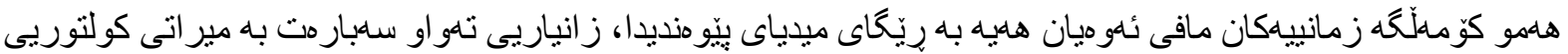

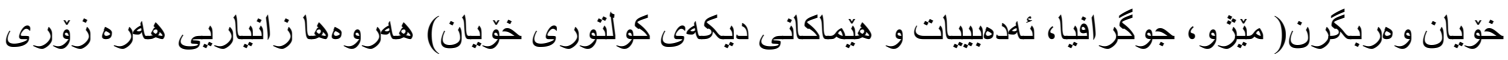

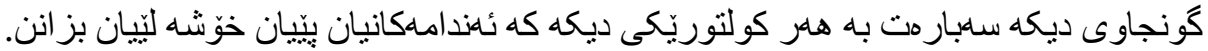

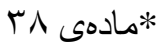

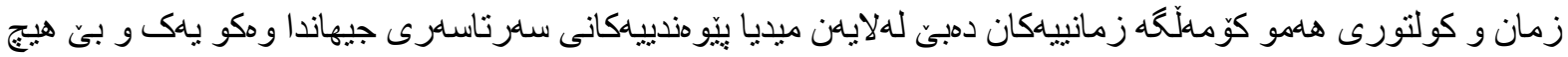

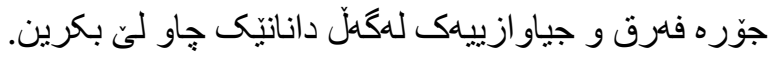

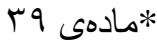

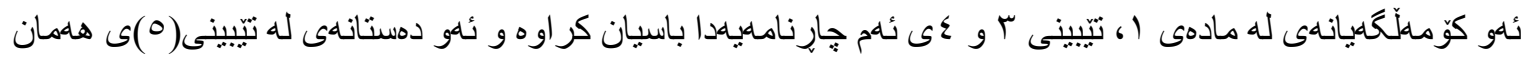

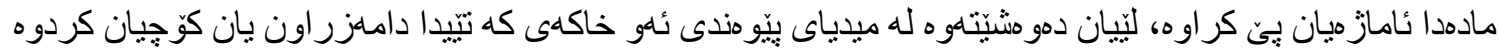

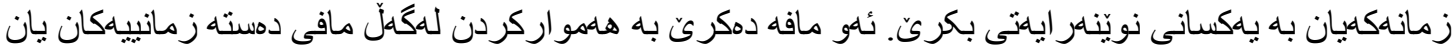

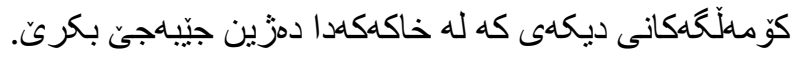

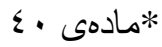

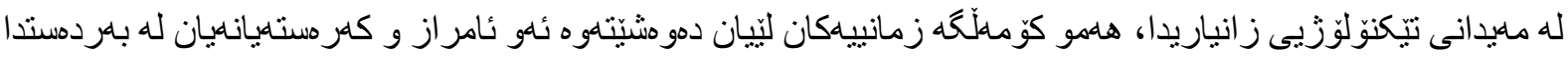

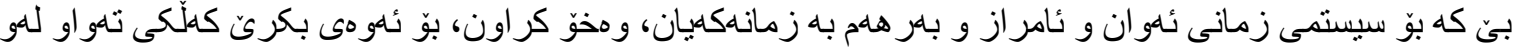

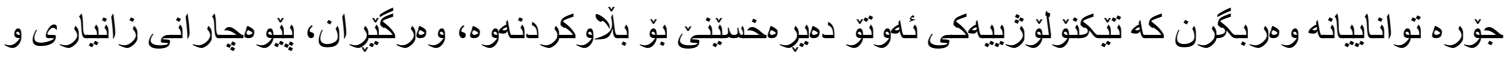

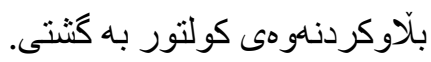




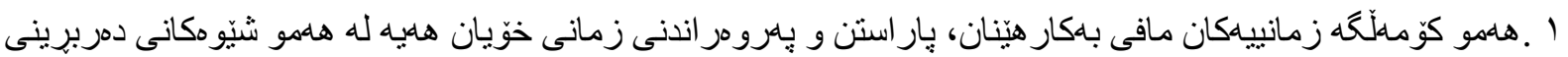
كولتوريدا.

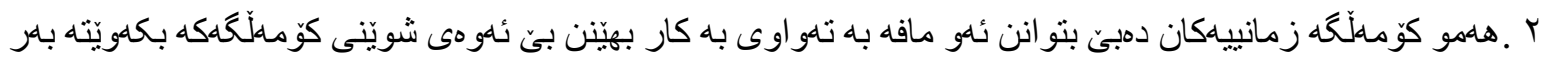

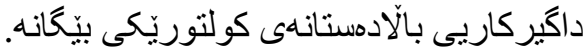

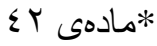

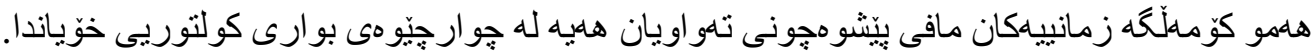

مادمى

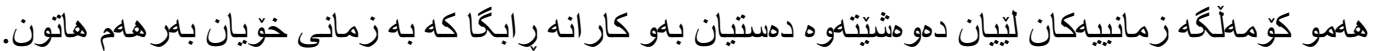

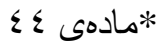

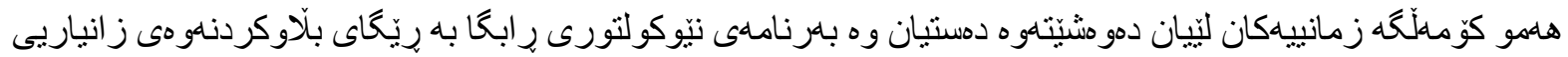

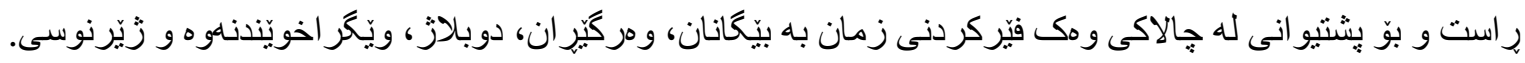

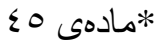

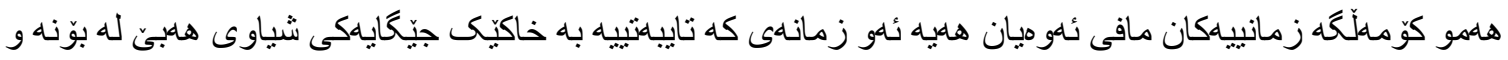

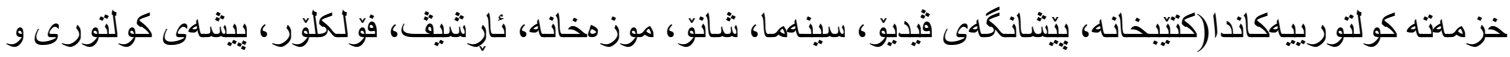
هامو هيّماكانى ديكلى زيانى كولتورىى).

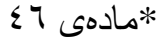

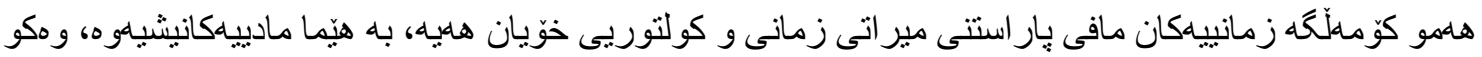

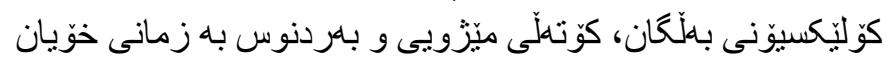

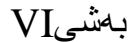

$$
\begin{aligned}
& \text { بو ارى كؤمةلآلايهتيى ئابورى }
\end{aligned}
$$

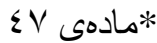

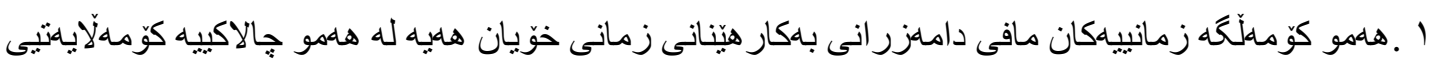

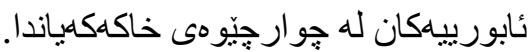

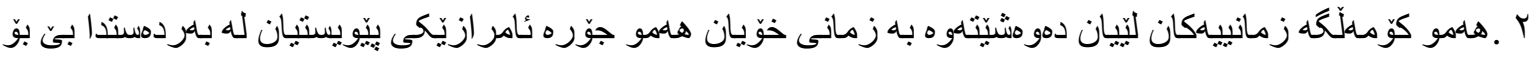

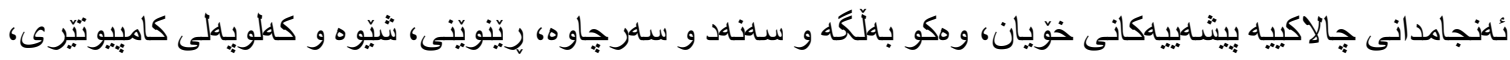

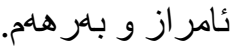

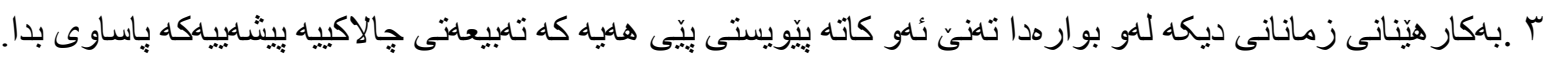

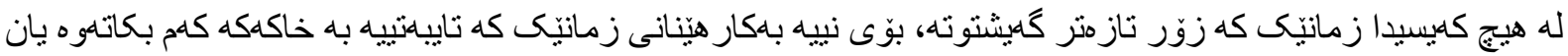
جيَّى بكريتينهو.

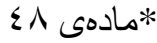

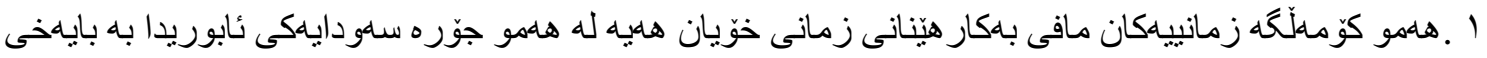

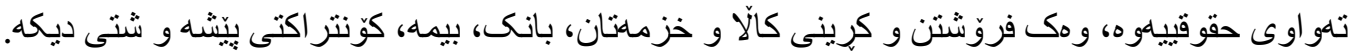

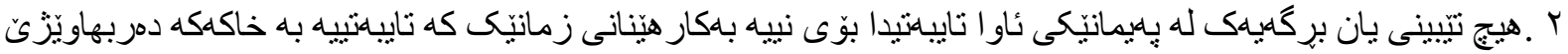

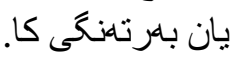




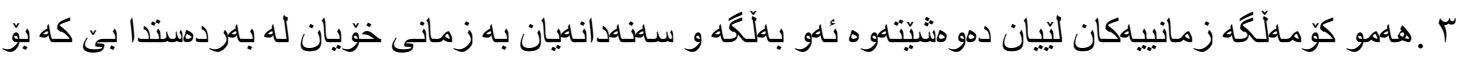

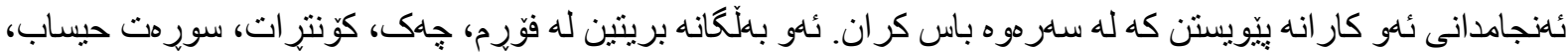

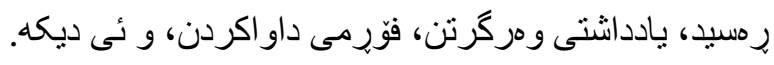

¿ 9 مادهى*

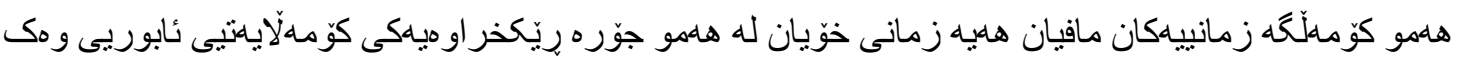

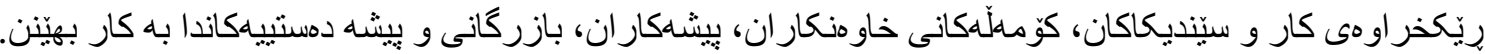

0. مادهى*

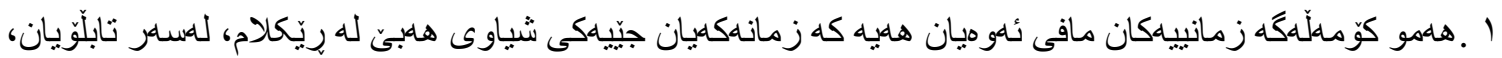

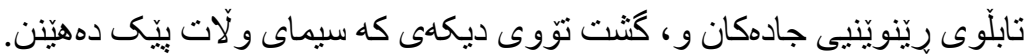

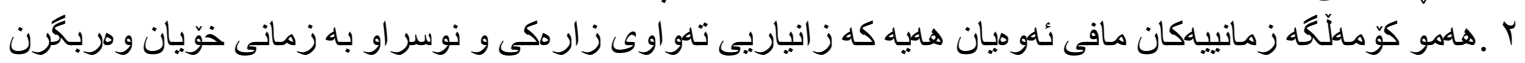

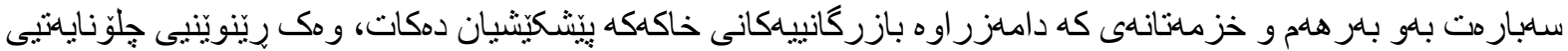

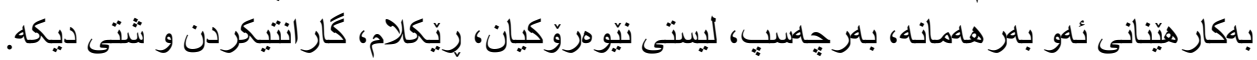

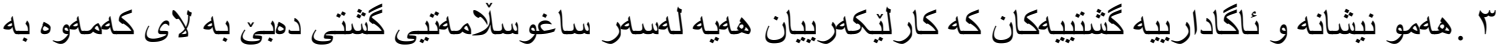

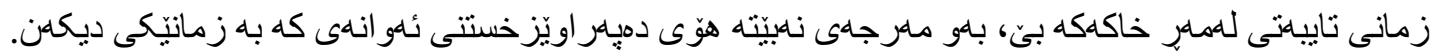

01 مادهى*

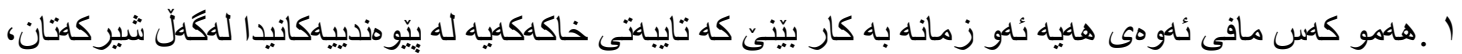

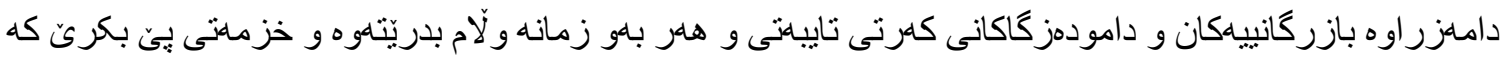

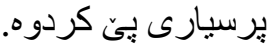

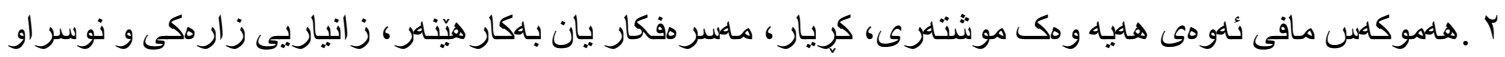

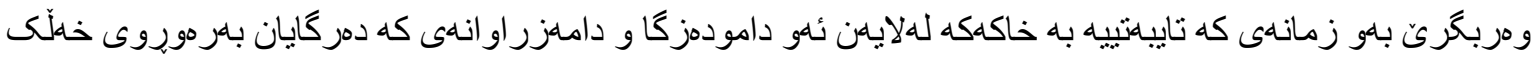
كر اوهيه.

or مادهى

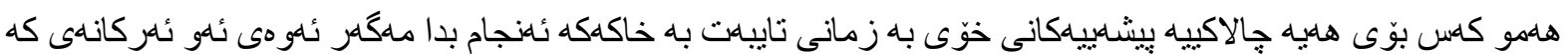

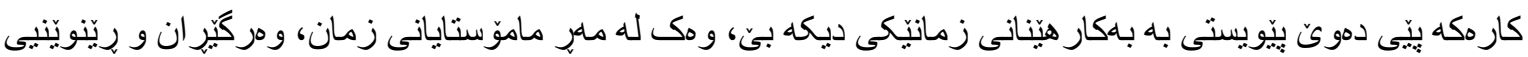
توريستان. 